\title{
SENSEMAKING FROM THE BODY: AN ENACTIVE ETHNOGRAPHY OF ROWING THE AMAZON
}

\author{
Mark de Rond \\ Cambridge Judge Business School \\ mejd3@cam.ac.uk \\ Isaac Holeman \\ University of Washington \\ iholeman@uw.edu. \\ Jennifer Howard-Grenville \\ Cambridge Judge Business School \\ j.howard-grenville@jbs.cam.ac.uk
}

July 25, 2019

\begin{abstract}
Drawing on real-time video, an audio journal, interviews and field notes from the first-ever attempt to scull the navigable Amazon, we explore the promise of carnal sociology to enrich our understanding of embodied organizational sensemaking. We investigate the body's role in sensemaking from two vantage points: "of the body" and "from the body". Using methodological and conceptual anchors provided in Wacquant's carnal sociology, we contrast what each approach tells us about the nature and process of sensemaking. Doing so helps us outline a complementary approach to embodied sensemaking that attends to (1) how a "new way of seeing" the body as sentient, sedimented, situated, and capable of suffering enables a more holistic understanding of the role of embodiment in sensemaking; (2) the importance this then places on the "who" of sensemaking; and (3) carnal sociology's broader methodological implications for organizational sensemaking.
\end{abstract}

This paper would not exist without the progressivism, moral support and direction of Associate Editor Tima Bansal and three outstanding reviewers. We would also like to thank Loïc Wacquant, Karl Weick, Jorgen Sandberg, and the PROS and OTREG communities for their feedback on earlier versions of the paper and their encouragement.

Finally, we thank those who made the voyage possible: Anton and Miguel, Ilyas Khan, Christoph Loch, Cambridge Judge Business School, Clare College (Cambridge), Gitzo, Metro, The Stanhill Foundation, JL Racing, Voyage Manager, Stonehage Fleming, The Moller Centre (Cambridge), ADEC Marine, Grey Dog, and The Cambridge Distillery. 


\section{SENSEMAKING FROM THE BODY: AN ENACTIVE ETHNOGRAPHY OF ROWING THE AMAZON}

"Once we acknowledge that cognition is a situated activity growing out of a tangled dance of body, mind, activity, and world ... you have the building blocks for a flesh-and-blood sociology, capable of producing multidimensional, polychrome accounts of social life that seize life as it actually unfolds, instead of the torpid reports in black and white that we now read in academic journals." (Wacquant, 2015: 4)

Organizational phenomena occasionally show up in surprising ways. Such has been the case with sensemaking for example, where classic discoveries were generated from studies of extreme contexts (Starbuck \& Milliken, 1988; Weick, 2010) and of temporary or minimal organizations (Weick, 1993; Whiteman \& Cooper, 2011). It is here after all that the relationships between making sense and enacting social structures are often most apparent and consequential (Bechky, 2006; Bigley \& Roberts, 2001). Indeed, as Weick's (1993) account of the simultaneous disintegration of sensemaking and structure in Mann Gulch demonstrates, a breakdown in meaning and its amplification across a small "outfit of men" can yield important insights into group dynamics, leadership and resilience in more conventional organizations.

Our paper follows in this tradition by leveraging extensive video footage and the embodied experience of one author in an usual context: an endeavor to scull ${ }^{1}$ the approximately 2,100 miles of the navigable Amazon unsupported. ${ }^{2}$ What began as idle talk turned serious such that late in the Peruvian winter of 2013, three men took to the water. Two of them did not speak either of the useful languages (Spanish and Portuguese) and neither knew much about a third companion who

\footnotetext{
${ }^{1}$ Sculling is a form a rowing where one has one oar in each hand, in contrast with "sweep rowing" where rowers each use one (larger) oar held with both hands.

${ }^{2}$ While this feat was recognized as a world-first, it is important to place it into perspective: given that the river is the only thoroughfare into the Amazon region, it is inconceivable that people haven't clocked up more impressive accounts in the past (even if not in a double scull). Moreover, the full (rather than "navigable") length of the river had already been kayaked, swum and walked, prior to our attempt.
} 
entered the fray at the final hour to keep them safe. Their boat had been badly damaged in transit and needed bailing out constantly on a river notorious for piracy and the traffic in narcotics. Pushing off from an embankment in Nauta (Peru), it quickly became clear that safety and efficiency would have to be worked out on an ongoing basis over 31 days and nights of more or less continuous rowing.

With its emphasis on how "people work to understand issues or events that are novel, ambiguous [or] confusing" (Maitlis \& Christianson, 2014: 57), one might reasonably expect the literature on sensemaking to have something to say about how the voyage unfolded. Equally, one might expect real-time data from this voyage to help advance our understanding of the body's role in sensemaking. In his original formulation Weick already recognized the role of embodied capacities, limitations, and personal histories in sensemaking; recall, for example, how Dodge, an "experienced woodsman," tried to lead his less experienced crew out of danger by lighting an escape fire in Mann Gulch. Yet reviews of the literature suggest that a long tradition of subsequent empirical studies have treated sensemaking principally as a cognitive and discursive process (Maitlis \& Sonenshein, 2010; Sandberg \& Tsoukas, 2015: 17). In response, recent work has begun to explore how specific aspects of being embodied shape sensemaking (Cornelissen, Mantere \& Vaara, 2014; Cunliffe \& Coupland, 2012; Heaphy, 2017). Successful attempts at locating the impact of visceral and emotional reactions, in turn, generated calls for greater attention to the "lived experience" of embodiment, to "bodily sensations, felt experiences, emotions and sensory knowing" (Cunliffe \& Coupland, 2012: 64), or to our perceptual experience and mode of presence and engagement in the world (Csordas, 1994: 12). Without such attention to the lived experience of sensemaking, we risk prioritizing outcome (sense made) over process (sensemaking) and favoring — because they are more easily available — traces of sensemaking that can be captured in 
spoken word or text. To focus only on the cognitive and discursive aspects of sensemaking then is to miss how sensemaking unfolds in action, perhaps fleetingly, through immediate and embodied “absorbed coping" (Sandberg \& Tsoukas, 2015: 17).

In this paper we respond to calls for novel empirical research into embodied sensemaking (Cunliffe \& Coupland, 2012; Gartner, 2013; Maitlis \& Sonenshein, 2010; Sandberg \& Tsoukas, 2015), and contribute to the broader conversation on organizational sensemaking that, by any account, has become a critically important topic in organization studies (Maitlis \& Christianson, 2014; Sandberg \& Tsoukas, 2015) that is central to decision-making (e.g. Cornelissen, Mantere \& Vaara, 2014), strategic change (e.g. Gioia \& Thomas, 1996), organizational learning (e.g. Christianson, Farkas, Sutcliffe, \& Weick, 2009), and innovation (e.g. Drazin, Glynn, \& Kazanjian, 1999). Over a hundred hours of video footage of the Amazon voyage, an audio journal, fieldnotes, interviews, and one of the authors having "perform[ed] the phenomenon" under study (Wacquant, 2015: 1), afford us a unique opportunity to explore how the body is complicit in sensemaking. For example, by exploring the video and interview data, using conventional coding techniques, we saw how the rowers probed their changing environment, took action within it, and communicated among themselves using their bodies. Yet, despite months of analytic work, the video footage left much of embodiment unaccounted for, including the role of physical transformation, intimacy, fear and anxiety in the embodied experience of sensemaking. This realization afforded us an opportunity: what if we were to generate two complementary, yet different, analytical accounts of the role of the body in sensemaking by leveraging all available data? The first of these, consistent with recent scholarship on embodied sensemaking (e.g. Cunliffe \& Coupland; 2012; Cornelissen, Mantere \& Vaara, 2014; Maitlis \& Sonenshein, 2010), would draw primarily on the video data to generate an account of the body. The second account would emerge from the body and be relayed 
in the first person. In addition to video data, it would also rely on a real-time audio journal, fieldnotes, and recollections of what it actually "felt like" for the fieldworker who performed the phenomenon under study. This latter account would leverage an ontology, epistemology and methodology advocated by the sociologist Loïc Wacquant, and referred to as "carnal sociology".

This paper is structured to reflect our use of these two distinct forms of analysis and the theoretical insights they afford into the role of the body in sensemaking. Each of two findings sections is preceded by a discussion of the distinct methodology used to generate and analyze the data. By drawing out contrasts between these two accounts, we develop specific insights into organizational sensemaking that are afforded by carnal sociology as a new way of seeing. These include: (1) how regarding the body as sentient, sedimented, situated, and capable of suffering (Wacquant, 2015) enables a more holistic understanding of the mindful body and embodied mind in sensemaking; (2) the importance this then places on the "who" of sensemaking; and (3) the broader methodological implications of carnal sociology for sensemaking. Our findings show how sensemaking is forged from, and into, corporeal experience, allowing us to transcend the truism that sensemaking takes sensory input into account and advance the more interesting claim that sensemaking relies on the details of our corporeal experience. We develop implications of these insights for more conventional organizational settings and suggest that a carnal sociology approach can enrich our understanding of sensemaking as it unfolds in processes like socialization, identity and change, and through everyday interactions around coordination or routines.

\section{ORGANIZATIONAL SENSEMAKING}

In their extensive review of the literature, Maitlis and Christianson (2014) highlight four features of sensemaking: (i) it is a process that unfolds over time; (ii) cues play a central role in triggering and shaping sensemaking; (iii) it is social; and (iv) it concerns action insofar as a sense 
of the situation enables people to act. Maitlis and Christianson offer a definition that includes these features in asserting that sensemaking is "a process, prompted by violated expectations, that involves attending to and bracketing cues in the environment, creating intersubjective meaning through cycles of interpretation and action, and thereby enacting a more ordered environment from which further cues can be drawn" (2014: 67). This definition also reaffirms three moves long considered central to sensemaking: noticing or bracketing cues, interpreting them, and taking action (Daft \& Weick 1984; Thomas et al. 1993).

To date, however, sensemaking scholars have paid far more attention to the interpretation of cues than to the other two moves: how cues are noticed and how they entangle with action. Sandberg and Tsoukas note that 84 percent of the studies they reviewed "do not seem to make a distinction between the "creation" and the "interpretation" process but treat them instead as one and the same. Thus, in contrast with Weick's early work, they argue that processes of sensemaking, as portrayed in the contemporary literature, have become "synonymous with processes of interpretation" (2015: 14).

This focus on interpretation gives the sensemaking literature its distinctly cognitive character, with several studies focused explicitly on how sensemaking updates or challenges cognitive schemata (Balogun \& Johnson, 2004; Elsbach, Barr \& Hargadon, 2005; Luscher \& Lewis, 2008; Starbuck \& Milliken, 1988). Other works adopt a constructionist perspective, asserting that sensemaking unfolds "in the discourses of social members - the intersubjective social worldrather than simply occurring in their minds" (Gephart, 1993: 1470; quoted in Maitlis \& Christianson, 2014: 95). Here, the emphasis is on how discourse and interaction guide sensemaking as it emerges between leaders and organizational members (Corley \& Gioia, 2004; 
Pratt, 2000; Maitlis, 2005; Maitlis \& Lawrence, 2007; Sonenshein, 2010). Still, "sense made" in these studies is discussed in terms that foreground cognition.

This predominance of attending to interpretation and foregrounding cognition stems from at least two sources. First, methodologically it is conceivably easier to study interpretation and the construction of meaning through narrative and discursive traces. Noticing and acting, on the other hand, are situated and fleeting, and less amenable to accurate post-hoc data collection. Second, interpretation fits readily with other intersubjective meaning-making processes that organizational theorists connect with sensemaking, including individual and collective identity (Corley \& Gioia 2004; Maitlis 2009; Pratt, Rockmann \& Kaufmann, 2006), organizational change, leadership, negotiation and power, and framing (Abolafia, 2010; Balogun \& Johnson, 2004; Sonenshein 2010; Rouleau \& Balogun, 2011).

Recent work calls for different perspectives, however. Sandberg and Tsoukas (2015:17) argue for attention to a more immediate, embodied "absorbed coping" as sensemaking, which would address Weick’s (2009: 130) original question of how people “[act] their way into sense." Others have begun to probe how sensemaking unfolds when the material world is present and consequential (Whiteman \& Cooper, 2011; Stigliani \& Ravasi, 2012), and people's bodies and emotions are implicated in how they act (Cunliffe \& Coupland, 2012; Whiteman \& Cooper, 2011). However, their data typically afford limited insight into the lived embodied experience of sensemaking ${ }^{3}$, and hence the interpenetration of action with interpretation or meaning. To overcome these challenges requires "adopting a more complex ontology than the one that

\footnotetext{
${ }^{3}$ An exception is Whiteman \& Cooper's (2011) paper which foregrounds the first author's role in performing the phenomenon to develop an account of "ecological sensemaking." Whiteman's lack of embeddedness in the harsh Canadian subarctic environment led to her slipping and falling into a river, risking drowning. However, despite the obvious implicit role of bodies in their account, Whiteman and Cooper do not theorize the role of bodies and bodily capacities in relation to sensemaking.
} 
conceives of the world as a collection of objects with specific properties" (Sandberg \& Tsoukas, 2015: 14).

One such ontology may be found in Wacquant's carnal sociology, situated theoretically at the meeting point of Merleau-Ponty's (1945/1962) phenomenology, Bourdieu's theory of habitus (1990, 2000), and the broad movement characterized as the "embodied turn" in cognitive science (cf. Clark, 1998; Damasio, 1999; Gärtner, 2013; Shapiro, 2010). Carnal sociology’s ontological claim is intuitively straightforward: the social agent is a suffering being of flesh and blood who relates to the world, acts in the world, and reflects upon the world using all available senses in processes shaped by a particular social biography and social position, and by social conditions and conditionings. As Wacquant (2018) explains, this ontology is an alternative to two prevailing views of agency in the social sciences today: that of homo economicus on the one hand, and homo culturalis on the other. The first presents itself as universalist, moved by the maximization of selfinterest; the second as historically specific, moved instead by culture and its variants (institutions, identity, symbols, language, etc.). Each of these is based on a Cartesian dualistic ontology that conceives of agency as an intelligent mind mounted on a what is effectively a dumb organism.

Carnal sociology views the body and mind instead as a single entity, such that the mind is embodied and the body mindful (Clark, 2016; Damasio, 1999; Scheper-Hughes and Lock, 1987; Shapiro, 2010). For Wacquant, social agents are forever located in physical and social space, endowed with resources, and equipped with categories, skills and desires (the three aspects of Bourdieu's theory of habitus). But while a carnal sociology negates neither the neo-utilitarian nor neo-symbolist treatments of agency (in a real sense, it subsumes them), these properties alone do not make for an embodied social theory, let alone a sensemaking that allows for "corporeal knowhow". Wacquant's (2018) call for a sociology of flesh and blood expressly recognizes that 
beyond thinking wielders of symbols, human beings are sentient, suffering, skilled, sedimented, and situated. They are sentient insofar as they are endowed with senses, able to feel and see and perceive and smell, to be conscious of doing so, and able to understand what it is their senses subjectively capture. As Damasio (2000) shows, the role of the body is critical in acting as the synthesizing medium of all this sensory awareness. But human agents also suffer in that they are "exposed to the threats and blows of the natural and social world; [have] needs, yearnings, and desires that do not get fulfilled; [... and they are] constantly subjected to the judgment of others while [facing] the inescapable coming of death. As such, [they live] in anguish, distress and pain, and yet they endure" (Wacquant, 2015: 3; cf. Becker, 1973).

Human agents are skilled, having learned how to do certain things competently. These skills are "implanted, cultivated and deployed over time through our engagement in the world, and are gradually deposited in our body as the layered product of our varied individual and collective histories" (Wacquant, 2015: 4; cf. Merleau-Ponty, 1945/1962). That is to say, skills are sedimented. This sedimentation, in turn, "is shaped by our unique location and peregrinations in physical and social space, precisely because we are protected by, and locked in, the fragile physical envelope of our mortal organism, which cannot be at two places at a given time [yet] integrates the traces of the many places we have occupied over time" (Wacquant, 2015: 4). In other words, agency is situated. These properties-symbol-wielding, sentient, suffering, skilled, sedimented, and situated - flow and evolve with time and are the building blocks for a flesh and blood sociology (Wacquant, 2015: 4).

Carnal sociology and its methodological program of "enactive ethnography" is perhaps most easily understood by contrasting inquiry that proceeds from the body, with more conventional studies of the body (Wacquant, 2018). Thus, and consistent with Wacquant $(2004,2005)$, our paper 
is structured along two distinct empirical analyses: of the body and from the body. Before elaborating on carnal (from the body) sociology, we describe our use of more conventional methods to study the role of the body in sensemaking on the Amazon.

\section{RESEARCH SETTING}

On $13^{\text {th }}$ September 2013, and after eight months of preparation, Anton, Mark and Miguel ${ }^{4}$ boarded a bright yellow ocean rowing boat in Nauta (Peru). Their aim was to reach Macapá (Brazil) within thirty-one days. At over 2,000 miles in length, bendy, and varying in width (depending on rainfall) from 200 feet to 120 miles wide, the Amazon is widely considered the world's most dangerous and most voluminous river.

So as to mitigate the risk of piracy, Anton and Mark decided at the last minute, at the strong recommendation of locals, to take someone else along. Miguel was afraid of no one, but nor did he trust anyone. A novice when it came to rowing, he had grown up in the jungle and had relied on the river for transport and sustenance (see Photo 1). While Anton and Mark had never rowed the Amazon, they were experienced oarsmen. Their intentions were multiple and only ever vaguely defined as an escape from the mess they'd been responsible for creating midlife. The idea had originally been Anton's. Mark figured that the journey might make for interesting research and was careful to chronicle everyday life on board, using an audio journal, fieldnotes, and video. Anton's eagerness to document the trip so as to try and commercialize the footage, is one of the reasons we have so much of it on film. To leverage the material for an exploration of embodied sensemaking was very much an afterthought. Indeed, we consider the absence of a research question prior to the actual journey one of the strengths of this paper, in that it greatly reduced the risk of anyone "playing to the camera" or "spinning a narrative" to suit a specific research interest.

\footnotetext{
${ }^{4}$ Pseudonym
} 
The oarsmen were required to check in with the Brazilian Navy at major cities along the route. During one of these obligatory stops in Manaus, Miguel decided he'd had enough and left Anton and Mark to continue the journey without him. What had originally been intended as an adventure for two ended just so, with two gaunt and sunburned oarsmen dragging a battered boat into a grubby Macapá marina. By that time, they had virtually depleted their supply of fresh drinking water, damaged the rudder, and lost two feet of keel and a considerable amount of bodyweight. Their satellite phone had run out of units and stopped working. As Mark recorded in his fieldnotes:

$\ldots$ and there really is very little else to say. We made our flight to Belem and onto Brasilia and Sao Paulo. Neither of us had time for a shower and so we sat out the various plane rides in whatever piece of clothing seemed least offensive. I flew to Sao Paulo barechested, having not one clean shirt to my name. We were hungry and thirsty for beer or Coke but anything cold would have done the trick. We were finally on our way home. We had lost thirty kilograms between us in body weight and were exhausted for rarely having slept more than three hours at a time for a month. Our egos were bruised, as were our bodies, and the minds that should have been quieted over the long row were noisier now than before we began. Our souls never did get mended and so fuck the purging. Before we got depressed, we were happy.

\section{METHODOLOGY I: A VIDEO-BASED ANALYSIS}

Data Sources. Our analyses rely on 755 video segments (ranging from under a minute to over an hour in duration), supplemented by recorded and transcribed post-journey interviews with two of the rowers. A substantial amount of the video data capture real time activity, as the camera, mounted on top of the boats' cabin and oriented towards the rowers was often left to run for long periods at random intervals (see Photo 2). We relied primarily on these videos in our initial analysis because they best capture (absent the tools of carnal sociology) the engagement of the body in sensemaking. Of our 755 video files, $602(80 \%)$ feature the rowers at work (with the camera mounted to the boat) or undertaking other activities on the boat or in towns along the way, and 153 (20\%) show one or more of them talking directly into the camera. In these latter "talking heads" 
video segments, one rower holds the camera in a "selfie" position and records reflections, while in the background others talk or work in a way that is manifestly inattentive to the camera- the mundane background work often proving more relevant to our analysis. Both types of footage were "real-time" in that they were recorded as events were still unfolding, the principal difference between these two types of footage being the speaker's reflective awareness of the camera. These talking heads videos are thus less analogous to post-hoc interview data than they are to the realtime informal interviewing that an ethnographer might intersperse with observations in the course of her fieldwork.

\section{--- Insert Photo 2 here ---}

A long tradition of the use of video data demonstrates their utility for the study of work, coordination and sensemaking (e.g., Christianson, 2017; LeBaron \& Jones, 2002; Liu \& Maitlis, 2014; Hindmarsh \& Pilnick, 2007; Harrison \& Rouse, 2014). Video has specific affordances, amongst which are a permanent and detailed record of "what happened", the ability to be viewed by many people and re-viewed many times, and audible and visual information that conveys nonverbal communication, sociomaterial interactions, and spatial configurations (Christianson, 2018). Video data are particularly useful for studying the fine-grained detail of socially and materially situated interactions (Hindmarsh \& Llewellyn, 2018). Each of these affordances proved important to our analysis. Our process, described in greater detail below, involved us attending to sensemaking opportunities and incidents as they arose (Heath, Hindmarsh, \& Luff, 2010) through the more (or less) mundane everyday action of rowing. We attended to incidents in the video that presented clues as to what the participants were engaged in; as Hindmarsh and Llewellyn (2018: 416) write: "Not all matter will matter for any one organizational moment. Rather, there is a prima facie case for privileging only those features that organizational members utilize, invoke or index 
in producing and coordinating action." Next, we detail how we oriented to these incidents in our data and analyzed them through iterative coding.

Data Analysis. The two authors not involved in the Amazon row led the analysis of the video data, supplemented by an analysis of interview transcripts. First, one author carefully watched all of the video data, and, consulting closely with the other author on what he was finding, summarized its content using a spreadsheet to capture which video segments would be subject to closer analysis due to their having captured episodes of sensemaking (Heath, et al., 2010). Of the 755 videos, 54 were found to be particularly illustrative of sensemaking. These captured instances of the oarsmen: i) negotiating daily ambiguities like navigating (37 videos); ii) working through more abrupt disruptive events like keel damage from running aground (14 videos), or iii) what Weick labels "cosmology episodes," or moments "when people suddenly and deeply feel that the universe is no longer a rational, orderly system" (1993: 633). The latter appeared in only three videos that capture the rowers' sense of unease as they were rowing in a tidal zone.

We re-watched and coded the subset of 54 videos, using a version (v7) of Atlas.ti able to handle video files. The two authors involved in the video analysis developed an emergent coding scheme. We paid attention in our coding to sources of surprise or ambiguity, and how the rowers responded to these. To refine the coding, these authors watched multiple video segments together and discussed the codes and their application. Mark was not involved in this coding work, although we periodically discussed our analysis together and he was able to elaborate on what was seen in the video. We applied codes to capture sources of daily ambiguities, using terms like "current," "wind," "bodily discomfort," and sources of disruptive events, using terms like "hitting [sand] banks and [river] bottom." We also applied codes to capture what appeared to be responses to these, including "dousing and drying their bodies" (to relieve the discomfort apparently due to 
intense heat), or "chasing currents" (to orient the boat toward an apparently more favorable current). Not surprisingly, the most frequently used codes were those relating to daily ambiguities and the need to maintain a schedule in the face of these.

Our analysis was enhanced by watching the videos in chronological order; through this, we were able to detect cumulative changes that were relevant to embodied sensemaking, but which might not have been picked up by looking at isolated incidents. For example, videos at a Karaoke bar days before beginning the voyage show a buoyant and seemingly well-fed team, a stark contrast with the gaunt, anxious, and emotionally frail men we see in the journey's later videos. We relied on the interviews with the two rowers, conducted separately and a few months following the row but prior to the video coding, to supplement our analysis. The interviews helped us understand the chronology and key events in the journey and by revisiting them we could fill in detail on how things observed in the video (e.g., the rowers paying attention to GPS readings) were being used to assess and respond to the unfolding situation (e.g., the speed of the boat held signals about the state of the current).

Several things became clear through our video coding and analysis. First, we could not rely on talk as a primary means of capturing unfolding sense in that rowing rhythm relies on felt experience. ${ }^{5}$ Similarly, rowers feel the water and get a sense of its movement from the way their boat is directed and the purchase they experience when their oars connect with it. Hence, the rowers typically said relatively little, communicating instead through gestures, expressions or movements of their bodies. Second, the body's physical and emotional states were implicated in sensemaking

\footnotetext{
${ }^{5}$ Anton interrupted an interview in a boathouse to hook two Concept II rowing machines to each other using sliders so the two authors conducting the video analysis could row, one behind the other, to feel how movements were transmitted between us. We were also able to get some sense of this from an exploratory double sculling outing on the River Cam. Our efforts to gain an embodied sense of the physical act of rowing helped us understand the video data by demonstrating how cues about water conditions, or other rowers' movements, could be revealed without words or explicitly communicative gestures.
} 
and these seemed to change over time. Moods and the tone of interpersonal interactions varied greatly, and while reasons for this — a tough stretch of wind, or someone having to disrupt another's sleep for assistance — were sometimes evident, they were not always clear to us. As Anton explains in one video segment: "You'd be impressed if we could record how much we're fighting. ... [but] you don't get to film these things. When things go wrong, you're too busy getting stressed and getting upset about it." Accordingly, we knew our video analysis would miss some aspects of the lived experience of sensemaking and how it unfolded.

To convey the results of our analysis, we focus on four instances of sensemaking. Three of these are illustrative of either instances of daily ambiguity (namely, a preoccupation with boat speed), or disruptive events (struggling with a whirlpool, and coping with physical injury, the latter of which also illustrates the cumulative disruptive effect of what began as a daily ambiguity of bodily discomfort). As is frequently the case with inductive qualitative analysis, we selected these examples because they are of analytical importance to understanding embodied sensemaking under different circumstances. Finally, our fourth instance is rowing in the tidal zone, which, as our dataset's sole example of a highly disorienting cosmology event, further enables us to explore the role of the body in diverse circumstances that demand sensemaking.

We make our video data accessible using QR codes (the default camera apps in most smartphones can read QR codes; free QR code reading apps are also available for download). Scanning a QR code will take the reader to a corresponding YouTube video. For convenience, each video comes with a "how to watch this video" caption, which the viewer optionally can use to scroll through and quickly see the most critical moments of each video. Photos are included 
purely for illustrative purposes. These visual aids are designed to bring the reader as close as possible to "the action". 6

\section{FINDINGS I: SENSEMAKING "OF THE BODY"}

Preoccupation with boat speed. While much work on sensemaking foregrounds the bracketing and interpretation of experience that triggers (cognitive) sense being made, our analysis reveals that sensemaking also relies on cues provided first and foremost by the sensate body. For example, much of the rowers' attention was consumed by navigating the daily ambiguities of where the fastest water flowed and how they might maneuver into it. Yet, this proceeded as much from the body's senses as from mental attention. For instance, one of our cameras caught Anton and Miguel in action five days into the journey. Music plays in the background and, rather than interact with the camera, they row with few words spoken between them. The ergonomic orientation of sculling is such that rowers propel the boat in the direction to which their backs are turned, which means that they must look over their shoulders in order to see where they are going. About one minute into the video, Anton glances over his shoulder and asks toward the bow of the boat, "you trying to head out into it?" Miguel replies: "Yeah, just [inaudible over music, glances over shoulder and gestures to the direction they are rowing]. Let's check it out." The two continue rowing for 70 seconds, during which time Anton makes a few comments about dolphins and Miguel remains silent but glances at the deck-mounted GPS six times. On the seventh occasion Miguel's gaze fixes on the GPS for nine seconds and then he glances over his shoulder to Anton, who sits behind him, and says, "Look how fast it picked up." As he says the words "picked up," Miguel gestures with

\footnotetext{
${ }^{6}$ For those keen to see more video segments of the journey, we have made a bigger sample available here:
} 
his head back to the GPS. Miguel then begins bobbing his head to the rock music just beginning to play from the onboard stereo. Seven seconds later he shouts to no one in particular, "WE'RE BACK IN BUSINESS". Six seconds later he stops rowing and turns around to offer Anton a highfive. Grinning widely (a rare occurrence for the typically stern Miguel), he gestures with his hands to the GPS in a self-congratulatory manner as can be seen in this video segment:

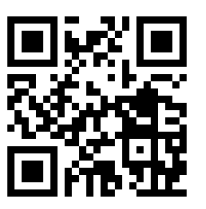

It is evident that the rowers' efforts were significantly experienced and communicated through feel, by their hands, legs, and backs noticing the movement of the boat and transmitting information about the boat's direction and the other rower's intentions through the boat and oars. Suspecting that they could be moving faster, and without talking, Miguel began to turn the boat perpendicular to their downstream course. Only after feeling Miguel beginning to turn the boat does Anton speak, asking, "you trying to head out into it?" Miguel literally acts his way in to sense, initiating his movement of the boat on a hunch — to "check it out"-and only knowing a stronger current has been found when he and Anton confirm the boat's quickening through GPS readings. This example captures the real-time engagement of the body as a sensory organ in working through the ongoing ambiguities surrounding the voyage. In a video diary filmed from inside the boat's cabin after this and similar episodes, Mark reflects on their emerging understanding of how to row the Amazon: 
We were just so exhausted, we didn't get very much sleep. So what we've done instead is just to accept that you don't really row the Amazon ... You don't attack the Amazon; it's too powerful. So what you do is ride it, and let it take you where you want to go. So the emphasis now is not on rowing as hard as we can. The emphasis is really on finding the fastest current and chasing it ... It makes the rowing lighter, it allows us to get a bit more sleep and makes the experience a little bit more pleasant than the misery it is if you don't get enough sleep.

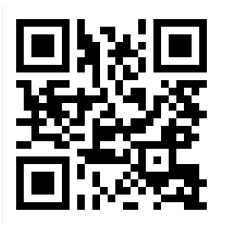

It is clear from these and many other video segments, and from our interviews with Mark and Anton, that "chasing currents" had become a major preoccupation on board. The Amazon is enormous and ever-changing, as tributaries come and go, and weather and water depth change frequently. As a result, it was often unclear where the river water was quickest, and a great deal of embodied activity such as that documented above was performed to seek river and rowing conditions that might get the oarsmen to their destination safely and quickly. Following a tough and demoralizing first night on the river, the rowers worked out over the next several days that average speeds of 6 miles per hour (MPH) by day and $4 \mathrm{MPH}$ by night were feasible, and that a 24-hour rowing schedule based on these speeds would see them to their destination on time. This provisional understanding was made possible, in part, by a GPS device that logged current boat speed down to a tenth of a mile an hour. Its readings soon became integral to the everyday work and talk on the boat, helping the rowers to take stock of the situation, e.g. "how's it going? Not bad, we're doing sevens" [meaning $7 \mathrm{MPH}$ ]. These anchors were at times used as aspirations for performance, e.g. "right, let's go spank out some sixes!" (meaning let's go row at $6+\mathrm{MPH}$ ), and occasionally enabled lively speed competitions among the rowers. As heuristics for attainable and 
desirable speeds, one could regard them as evidence that sense had been made of how the rowers could cope with the unfolding contingencies of rowing day and night in all weathers, by "hitting the numbers."

Miguel was proficient at reading currents and taught the others to look for moving debris and pay attention to the potential for faster flowing waters near river banks. But, as the above example illustrates, even he still had to "hunt" for them. Hunting for currents did become a standard bodily practice as well as topic of daily talk, and the heuristics for what constituted a "good" boat speed were taken only as guides for action. For example, even quite late in the voyage, Anton was captured on video saying:

It's a guessing game for us, because we're not from here. The locals know where the stream [current] is. Miguel knew where the stream was in Peru, although on the bigger river he struggled as well.

Struggling with a whirlpool. The unending ambiguity of navigating the river in a way that preserved both boat speed and the rowers' capacities to produce it was occasionally punctuated by discrete episodes that demanded collective reflection. One such moment was caught unintentionally on camera, confirming the methodological utility of real time video. The camera had been running continuously inside the cabin for 52 minutes when Mark, who was rowing alone, called from outside the cabin: "Does it matter which side I'm on Miguel, or not?" After repeating his question, the reply from Miguel came: "Yeah, look for the one has the stronger current." Mark replies: "Okay, that's fine. That's what I'm trying to do but it gets, I get pulled in this direction," and gets cut off by Anton announcing he will have a shower. Five minutes later, Anton asks “Where you trying to go?”, to which Mark replies: “I'm trying to go back, but whatever ... I can't row when I'm pulled to the side. The rudder is always pulling ... it's almost like a whirlpool but I can't see one." As is evident in the following video, Mark continues to struggle with maneuvering 
the boat in the water, takes guidance from Anton on using the rudder, but expresses frustration about his inability to move out of a "sideways pull" in the water that only he can directly feel. Miguel eventually surfaces from the cabin, surveys the water, and directs Mark to "avoid a bay" to one side of the boat, leading Anton and Mark to surmise there is a shallow area where water is not flowing as expected. Despite making sense of the unexpected situation-here through the familiar mechanisms of talk and interaction — and a course of action through which to escape the whirlpool, the feel of this ambiguity rests with Mark, as does the feel of his inability to escape it. This is evident in the following video segment:

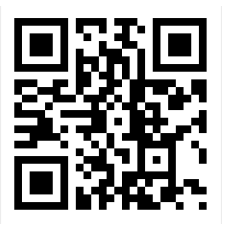

Rowing in tidal waters. The bodily sensing of ambiguity arises again in a more profoundly disorienting episode much later in the voyage. Here, the experience seems more reminiscent of what Weick calls cosmology episodes, or moments "when people suddenly and deeply feel that the universe is no longer a rational, orderly system" (1993: 633). Less than a week before the end of their journey, Anton reflected on camera: "We are getting heavily crucified by the wind today ... we can't control the boat." He added that sustaining a respectable boat speed, and chasing currents to attain it, seemed no longer possible, saying "We might only be ticking over at $31 / 2$ or $4 \mathrm{~km}$ per hour, but ... we're still moving forward. We're not so much rowing with the stream [current] as just sat on it, trying to keep the boat pointing in the right direction."

Rough conditions and slow progress pervaded subsequent days and the rowers adjusted by shifting their rowing schedule to prioritize rowing together rather than in turns and, prior to that, in 30-minute shifts to preserve their backs. Four days before the end of the journey, Mark described 
the situation as "very, very tough, morally ... and also physically, Anton and I are very, very tired." Just over twenty-four hours before the end of their journey, they pass through a series of islands on very swift current only to hit an invisible wall. They were making so little progress (1.5 to 2 $\mathrm{km}$ per hour) while rowing so hard that they began to feel as if they were rowing against the current. After rowing close enough to the bank to put down anchor, they turned on the camera as they tried to test the possibility that tides had become a factor; the idea initially seemed incredulous as they were still over $100 \mathrm{~km}$ from the ocean. They threw bits of tissue into the water to see if these might perhaps drift backwards. They discussed waiting for the tide to change to see if their boat swung around the anchor. They also used the satellite phone to ask a friend to search online for information about how far up-river the tidal zone extends. The answer came back while the camera was still rolling, and Mark reported to Anton: "She says here the tide affects much beyond $100 \mathrm{k}$ in. So, I think we've already felt the effects, but we haven't realized what the effects were." Put simply, the week's hard rowing had been reflective of a new set of conditions, and while they had revised the bodily task of propelling and maneuvering the boat as they felt the effects, their full sense of the situation lagged.

Coping with physical injury. Part of the reason for their delays in making sense of the tidal current might have been the toll the voyage and its ambiguities had taken over time on their bodies. Choices made earlier manifested in unforeseen consequences. The most telling examples of these came from the work the rowers were doing to maintain their physical conditions - and some degree of comfort — that would enable them to go on. While clearly their bodies felt the oars and the water currents, they also felt discomfort and worked through it. For example, Miguel, new to rowing, quickly found his hands blistered where they connected to the oars, a common novice rower's scourge. Asking Anton for advice: “what do you do about blisters?", attracted only a brusque and 
unsympathetic response: “man up!” Indeed, an experienced rower will have rows of calluses at the base of the knuckles that prevent blistering as the oars are gripped and rotated. The day after being told to man up, Miguel is seen sporting athletic tape in no fewer than nine places on his hands (see Photo 3) and wearing gloves to protect the raw patches. But the body can also transform over time to enable, rather than disable, its capacity to feel and perform. Over a week after the first video of Miguel puzzling over his blisters, another shows him casually massaging his calluses and picking flakes of dead skin off of his hands, which at this point are not taped and not so visibly blistered.

--- Insert Photo 3 here ---

Some bodily maintenance practices had more enduring effects. To cope with the heat, Miguel and Mark had begun to douse themselves in river water while rowing. Anton seemed aware early on of the potential risks of this, saying on video: “They've taken to sloshing themselves down with water during the day while they're rowing, which is all well and good, but I have pointed out that ...[if] they've got water loitering around down there at the crack of their rear, that there's a good chance they'll get a massive blister there. ... But, still, that's what we've got the nappy [diaper] cream for." Over time Mark and Miguel did both develop painful cases of "nappy rash," and only then stopped drenching themselves. In Mark's case, a significant abscess set in on his buttock that made sitting (and hence rowing) increasingly painful. One video shows Mark proudly and jokingly displaying his newly purchased nappies, acquired at a shop in Santorem, there to cushion his rowing seat until the abscess had grown so large that he chose to cut a hole in his rowing seat instead (see Photo 4). A gripping video late in the journey shows Anton performing a small surgical procedure, without anesthetic, to drain the abscess because its risk of spreading infection was thought to be substantial.

--- Insert Photo 4 here --- 
In sum, our analysis using the video data as a primary means of detecting the real time engagement of the body in sensemaking revealed that the body's capacity to "feel" its surroundings, or its sensate nature, can be critical to finding a sensible way forward. The relative lack of talk in many of these sensemaking episodes highlights the importance of the body not simply in service of the mind but also as a means of acting into sense. These findings also affirm a social aspect to embodied sensemaking, as the communication of one sensate body to another can enable joint action (as when Miguel and Anton chase currents) or the lack thereof can forestall it (as when Mark finds himself stuck in the whirlpool). As well, they suggest a highly individual aspect to embodied sensemaking, insofar as it relies on the physical state of individuals' bodies that evolve (differently) over time.

Below, we proceed to outline "a new way of seeing" the same four episodes, leveraging a from the body approach as outlined in Wacquant's (2005) carnal sociology. This will show up some key differences in how the holistic body is fully engaged in sensemaking, in a way that implicates not only its physical status but also its emotional and relational state, and how these are situated temporally, culturally and socially.

\section{METHODOLOGY II: A NEW WAY OF SEEING}

Given that one of the authors "enacted" the journey, we are in a position to augment these findings by means of a "lived experience" ethnographic account. We wrote Findings I to illustrate what we were able to learn by analyzing real-time video and using interviews as supplementary sources. We emphasized how the body can prompt sensemaking through its "feel" for its surroundings, and how this enters into interaction and eventually, articulated sense. In contrast, Findings II renders a full-body account from the perspective of the author who performed the phenomenon, drawing on 62 audio journal entries, fieldnotes, and the recollections these generated 
of "how things felt" during the row. By developing this analysis of sensemaking "from the body" alongside a more conventional analysis of video data, we seek to clarify how an enactive ethnography, as proposed by Wacquant (2005), can help advance our understanding of embodied sensemaking. We compare and contrast the two analyses in our Discussion.

To structure our interpretation and give it analytical bite, we ground it in an approach to social analysis known as carnal sociology. This theory-method bundle was developed as a response to overly intellectualized treatments of social life, in which human beings are principally viewed as mindful, rational, speech-act performing social and political beings. This intellectualized perspective overlooks people's experiences as beings of flesh and blood, "sensate, suffering, skilled, sedimented, and situated corporeal creatures" (Wacquant, 2015: 2), fully able to capture the "taste and ache of action" (Wacquant 2004a, pp. vii-xii).

Wacquant is not the first to draw attention to the risks of a "head-locked" approach to social analysis. As Dall'Alba, Sandberg \& Sidhu (2017: 1) write, others have attempted to capture how the body relates to other humans and to the world around it, including Foucault's (1977) focus on the body as an instrument of power, Giddens' (1986) elaboration of practical consciousness, Young's (1990) prolegomena to bodily comportment and gendering, Grosz's (1994) description of bodily inscription by discursive systems, and Sheets-Johnstone's (1999) exploration of the primacy of movement. Moreover, there is a now-burgeoning field of embodied cognition based on the intellectual roots of Martin Heidegger, Maurice Merleau-Ponty and John Dewey, and greatly advanced by George Lakoff and colleagues (e.g. Lakoff, 2008; Lakoff \& Johnson, 1999, 2008; Lakoff \& Núñez, 2000) and leveraged to powerful effect in, for example, treatment of trauma (e.g. Van de Kolk, 2013). 
The ontological assumptions of carnal sociology (as outlined earlier) are accompanied by an epistemological claim, namely that the forging and workings of habitus are fully open to empirical investigation. Wacquant (2014a, 2014b) argues that what is true of human beings in general is also true of the social scientist: if people "out there" know the world through sensory engagementthrough tacit schemata acquired in and for practice—organization scholars can tap that knowledge by subjecting themselves to the same forces, profits and perils as the people they study. Wacquant's (2018) ontological claim that human agents are sentient, gendered, sexual creatures who suffer and are fated to die (and aware of this) is, he argues, typically dismissed by social scientists or reduced to irrelevance (meaning that the brute fact is acknowledged but judged as of no consequence for their investigations) (cf. Bourdieu, 2000). The alternative, proposed by Wacquant (2018: 2), is a view of knowledge that is "procedural, concrete, embodied, and predicated on a bottom-up, visceral grasp of the social world (which all of us have prior to positing objects through language and discursive knowledge)". The knowing body is not a "black box", in that it does not stand beyond the realm of observation. On the contrary, the techniques whereby it is forged, the ceremonies in which it is invested, and the manners in which it is deployed are all, Wacquant (2018) suggests, available to investigation.

It follows that the most effective methodological approach to this fully embodied sociology is likely that of close up observation through pragmatic involvement in concrete activities (Wacquant, 2015: 4). This opens the door for what Wacquant calls "enactive ethnography," or the embedded and embodied study of a phenomenon by performing it (or parts of it). Enactive ethnography, while resembling autoethnography, is distinct from it. Enactive ethnography considers the self a means of inquiry rather than an object of study, as is more typically the case with autoethnography. As he explains with reference to his study of pugilism (Wacquant, 1995a; 
1995b; 2004; 2011), "enactive ethnography relies on the most intimate experience, that of the desiring and suffering body, to grasp in vivo the collective manufacturing of the schemata of pugilistic perception, appreciation, and action that are shared, to varying degrees, by all boxers, whatever their origins, their trajectory, and their standing in the sporting hierarchy" (Wacquant 2011: 146). His account is not just of the body as sociocultural object, and nor is it about the subjective self; it is from the body and about growing up in a hard-luck South Chicago neighborhood.

Similarly enactive studies of social life include Desmond's (2007) study of wildland firefighters, based on his experience as a member of a fire crew in northern Arizona; Purser's (2009) exploration of the life of day laborers, based on her experience as a day laborer over three years in Oakland and Baltimore; Pachirat's (2011) covert study of working life inside an industrialized slaughterhouse; and Holmes' (2013) analysis of Mexican migrants in the American food system, having crossed the Mexican-US border illegally with his informants and joined them in planting and harvesting corn and strawberries. Each takes full epistemic advantage of the visceral nature of social life, by means of (or from) the body. Yet such analyses of social life remain scarce in the social sciences, and rarer still in organization studies.

The findings that follow are written in the first person. They are based on multiple reviews of the video footage of the episodes discussed in Findings I as well as a documentary film based on a compilation of the available footage put together by Anton. I replayed 62 audio diary entries recorded by Anton and me in the relative privacy of our small cabin, and re-read my field journal, excerpts of which are offered to help "authenticate" and enrich the account. The ensuing enactive ethnography is the result of multiple dead-ends prose-wise as I struggled to convey in words what it all "felt like" at the time, and how it was that our bodies sometimes "knew" what our minds did 
not, or didn't seem to. To force embodiment to become text is, to quote the historian Trevor-Roper (2014: 139), a bit like forcing "a jellyfish to grit its teeth." That is to say, the resulting account may be imperfect but is my best attempt yet at capturing something of the corporeality of sensemaking.

\section{FINDINGS II: SENSEMAKING "FROM THE BODY"}

Findings II offers a carnal sociology interpretation of the same episodes discussed in Findings I. When reading the incarnate account (immediately below) across these same episodes, readers may be surprised to find features of sensemaking foregrounded in Findings II that are absent from Findings I. If certain features do not figure in Findings I, it isn't because they aren't there-it is because they did not (easily) show up in the available data. Among these are experiences of fear and anxiety that, while rarely explicit in the video data, were among the most visceral. There are few more poignant reminders of the embodied nature of emotions then feeling the adrenaline coursing through one's veins after a near-collision on a deadly river, days away from any medical assistance. It thus seems appropriate that we begin Findings II by illustrating the extent to which these emotions conditioned our reactions to the changing circumstances in which we found ourselves. Occasionally, as is the case here, a new way of seeing calls for a new way of writing. It is near-impossible to do justice to the finely textured, manifold experience of embodiment in prose, particularly within the strict conventions of scholarly journals, and to do so requires a level of intimacy and imagination more easily afforded by the informal and straight-talking than by the formal and analytical. Thus, the ensuing first-person account is deliberately free of the latter, beginning as it does with disappointment.

Our yellow vessel, when it did finally arrive four weeks late, had been clumsily dropped onto the rocky shores of Nauta, a small commercial settlement on the north bank of the Marañòn River. Eager to be on our way, we pushed the boat into the fast-flowing river only to find it taking on 
water at alarming speed. Rarely ever was the plunge from the audacious to laughing stock more rapid as, tails firmly tucked between the legs, we asked for the boat to be towed into dry dock, where we spent 12 hours repairing the consequences of a careless drop. Seeing as Miguel had used up all of our spare epoxy in waterproofing our rudder, he made his way back to Iquitos on an offroader to source some there. Anton, meanwhile, was miserable, angry at Miguel for having wasted our precious material and not at all sure the leaks were fixable. By the time we finally put the boat to water yet again in the early evening, we were emotionally spent. I ended up rowing for most of the first twelve hours so as to give Anton a chance to patch up the boat from the inside while Miguel learned to row in spurts. The following video shows the emotional strain of four weeks of waiting for the voyage to begin, only to find the boat badly damaged.

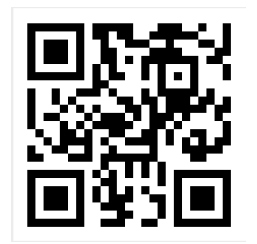

When setting off from Peru, I feared the worst of the row to be the mundane and ordinary: the tedium of rowing, petty irritations, exhaustion and lack of hygiene. These were what I had least looked forward to yet, I figured, might be valuable research-wise. Ethnography is, after all, the study of lived experience, and whilst a trek downriver might seem out of the ordinary, in reality it would likely comprise plenty of monotony. And so here I was: a subject in an experiment of my own making, caught out on our very first night by a violent storm, wind and waves pushing us dangerously close to oncoming traffic. Rowing at night was to become one of our chief sources of anxiety, not least as the river's elongated and unwieldy, flat-bottomed cargo barges go merrily about their business with all lights turned off. This made them unusually difficult to spot but—and this was genuinely unnerving — easy to hear as the noise of their diesel engines easily cut through 
the black surroundings. That first night, the rain and wind carried wasps, and the wasps stung, and by morning we were dog-tired and sore but strangely content. As the sun finally rose, temperature in tow, the skies dried out, and a heavy-eyed Anton reappeared from our small cabin, wondering what all the kerfuffle had been about.

By this time, Anton and I had known Miguel for a week. We had originally intended to row the river by ourselves yet four weeks in the company of locals and expats had left our heads filled with stories of schemes gone awry and of adventurers robbed and butchered in the most brutal of fashions. The Amazon, after all, is notorious for piracy (Romero, 2016). It was for this reason that we had co-opted Miguel. Scar tissue where bullets had entered his abdomen, a laparotomy scar and a powerful, sinewy body meant we didn't ask too many questions about his background. Nor did he volunteer much except, on one occasion, his notch count. On reflection, I doubt we would have gotten as far as we did without him, even if his presence on board gave us far greater cause for concern than did the prospect of a run-in with the thugs he was there to protect us from.

In the end, Miguel put up sticks shortly after we had moored up to check in with the Navy in Manaus and left us to our own devices after having finished the necessary administration. Miguel told us he was flying back to Iquitos. He had been disappointed at not having been able to leverage the row to showcase the beautiful yet fragile jungle and wildlife of the Amazon region. Frankly, I suspect the madness of life on board may have done his head in. He also said he'd wanted to hunt down a "pirate woman" he was sure had stolen his passport on a tow into the Teffe harbor. ${ }^{7}$ Anton and I were upset, not least as we'd compensated him for six weeks of "lost income" and he had

\footnotetext{
${ }^{7}$ It is doubtful this woman was a "pirate" in the sense pirates are referred to in this paper. Pirates on the Amazon are typically opportunists who view tourists as easy prey. The public record holds plenty examples of piracy on the river. As of writing this paper, the most recent incident involved British kayaker Emma Kelty, killed in September 2017 on a stretch of the Amazon well known for criminal activity (http://www.bbc.co.uk/news/uk-41321514). Our "pirate" woman had been kind enough to tow us into port and acquired the name for wearing an eye patch. Miguel's passport was subsequently found at the bottom of Anton's backpack.
} 
only been with us for four. Given a spat about expenses the previous night, it was unlikely he would reimburse us, and neither Anton nor I were keen to try our luck. It wasn’t our first, nor last, quarrel and quarrels happened far more often when moored up than when rowing on the water.

Yet Miguel's departure had one welcome consequence: after two increasingly stressful weeks, peace finally returned to the ship, at least temporarily. The extent of our emotions is evident in a video recorded shortly after setting off again from Manaus:

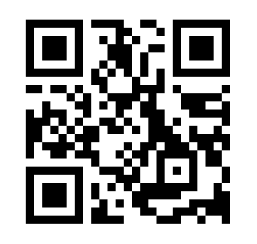

As Anton put it in our audio journal:

[Before leaving for Peru] we were [...] worried about pirates and infections and how we thought our strong point was our teamwork, and the things we thought were dangerous were actually quite safe, and the things we thought were safe and very positive were actually the bigger danger to us while we were out here ... [then audibly chuckling] this is probably one of the most profound things I've ever said in my life.

While Miguel and Anton had little difficulty voicing their discontent, I was more guarded in expressing mine, though I did so privately, in my fieldnotes:

Look at the state of us. There's so little that is beautiful: the fiery swamp inside reeks of selfishness and opportunism and hatred. There is no love of neighbor. There is not even love of self. What there is instead is a self-loathing and ruthless desire to fill that aching void by means of deception by living off the hopes of easy prey, feasting on those less assertive or more gullible, and when these coffers are empty then to feast on each other instead. Our hunger, alas, is never satisfied, for depravity and loathing are bottomless.

Looking back now at the footage, audio journal and fieldnotes, our reactions were neither balanced nor fair (and not least as far as Miguel was concerned). But we were angry, resentful, and had been 
robbed off any illusion that this row might actually be an enjoyable adventure. We had become afraid, and for having been made to feel afraid, found our pride hurt.

This may explain the euphoria we felt as Anton and I powered east towards the point where the Amazon and Rio Negro rivers meet and, given their temperature differences, don't merge until several miles downstream. We playfully navigated the razor-sharp line separating the two rivers while the fun lasted, the milky-tea colored Amazon on bow-side and the pitch-black Rio Negro on the other. Little did we know that our most terrifying experiences were still ahead of us: a nighttime Catch-22 "escapade" with drug traffickers and a near-miss with a cargo-carrying barge. By this time, we'd enjoyed several narrow escapes already as boats passed uncomfortably close. Smaller vessels included fishing boats and those ferrying passengers for which we were entertainment. At night, we faced barges and fast-moving speedboats. The latter only featured in a short stretch of river popular with narcotics traffickers, their powerful boats zipping from bank to bank, perpendicular to our direction of travel. They went about their business under the cover of darkness with all lights off, presumably not expecting much in the way of traffic. Because we didn't fancy our chances upon discovery, we too kept our navigation light off, skulking the river in a "damned if you do, damned if you don't" fashion, focused on the probable rather than possible.

Cargo barges, by contrast, made deep, rumbling noises. They typically comprised large pontoons, three or four at a time, driven upstream by a diesel-powered push boat in complete darkness, with the exception of a powerful beam that would scan the tree-line every so often. Seeing as they typically hugged the riverbank, we had resorted to moving closer to the middle of the river to given them a wide berth. As our own navigation light polluted our line of sight (seeing in the dark was difficult enough as is), we would often hear but, until the very last moment, not see an outline of the convoy. 
In the dead of night, early into my shift, I registered the sounds of a diesel engine. By this time in our journey, Anton and I had developed habits to help us cope with nighttime mosquitos and clammy nights. So, to fight off insects, Anton rowed in a zebra-patterned onesie, acquired pre-trip to humor locals, while I preferred to use the cover of darkness to row in the buff. I expected the sound to pass, as it had on many a night. It grew louder instead. Spooked, I grabbed a flashlight to find a pontoon heading straight for us and now nearly on top of us. A collision would have capsized the boat; the cabin would have filled up, and Anton would surely have drowned. Had I survived, I'd have been left in the middle-of-nowhere, stripped of any material possessions. The guilt of Anton drowning on my watch would have likely dispatched me, even if nothing else had. And so, my body did the only thing it knew now to do: it roared. It needed to rouse Anton. It also began to backpaddle mightily, unthinkingly, pushing the stern backwards to get the boat out of harm's way while Anton, delirious with sleep, hand-pumped a plastic horn to awaken the jungle. We lived to tell the tale, of course, and learned to snigger it off over the next few days, as one does, imagining the captain's surprise at discovering a bright yellow vessel, a man in a zebra suit, and another up to no good.

\section{--- Insert Photo 6 here ---}

I elaborated on our experience of fear because the accumulation of it was deeply felt and fully embodied, and moral and physical depletion were both context for, and means of, sensemaking. What we did and didn't do can only ever be understood (if not excused) when appreciating "how things felt" at the time. In the example above, I referred to my panicking self as "it" to reflect that my reaction was instinctive and deeply corporeal. Such experiences meant that our sensemaking around encounters with locals, changing weather conditions, and night-time rowing was typically 
tilted in favor of foe rather than friend, risk rather than rewards, and the dreadful rather than the beautiful. And it is against this background that we reconsider the four episodes from Findings I, this time "from the body" as a new way of seeing.

Preoccupation with boat speed. Boat speed and safety rapidly became our chief concerns. Finding fast-flowing water on the Amazon takes considerable skill because it is very difficult to see differences in the flow of water across such a large river. As explained in Findings I, we used our GPS for speed readings, able to tell whether we had moved into a faster current. But what our GPS couldn't tell us is whether a higher speed reading was the result of greater efficiency or greater exertion of power on our end. Speed was only ever accurately assessed by our bodies knowing how hard they had to work to achieve a particular GPS speed reading, whether this involved more, or less, effort than was the case with a previous current, and whether maintaining this effort was sustainable. Head winds offset boat speed and gusts pushed the boat off stream. Choppy waters changed the oar's purchase in the water while islands, submerged sandbanks, and side streams altered the current. Shortcuts sliced across large bends in the river but would often pass through stagnant water. Even with access to an electronic map upon entering Brazil, the map did not account for the fact that flood waters constantly change the path and shape of the Amazon and its innumerable tributaries, islands and sandbanks.

Such sources of ambiguity quickly became ordinary, with the result that GPS location readings and boat speed were never ready-to-use indices of our circumstances. Rather, making sense of location and speed involved a certain kind of work: judging boat speed in light of salient features of the situation, including our perceptions of local topography. Sensations from our bodies, such as the build-up of lactic acid in our leg muscles, were guides to how hard we were working to maintain a given speed. When our backs were too sore to continue zigzagging across the river in 
search of faster currents, we would look for floating debris: if stuff traveled faster than the boat, it was riding a faster current. When debris was too far out or unavailable, we would aim for the river bank: steep banks indicate deep waters, and deep waters faster currents. But maneuvering close to the bank held its own ambiguities; depth was difficult to perceive in the opaque water, and sandbanks were an ever-present risk of us running aground.

The impact of a river current on speed wasn't foreign to either of us. As active members of a rowing community for most of our adult lives, we were well aware of boat speed being a function of the ability to leverage fast flowing water, and of rhythm (or coordination). The experience of rhythm in rowing is almost entirely visceral yet does not rely on any specific sensory perception. It relies on neither cognition nor speech acts—it isn't an intellectual accomplishment—nor is it clear where in the body the feeling is located. Rather, rhythm is felt throughout the body (de Rond, 2008; Ingold, 2011: 60, in Dall'Alba et al., 2017: 10). For example, a few days into the journey, we decided on an impromptu competition, rowing alone, and in various combinations, to see who was quickest. Anton and I, as a pair, easily came out tops, not because we were physically stronger but because our bodies knew how to coordinate so as to feel, and adjust, their way into a powerful rhythm. We coordinated through felt experience, meaning that our bodies sensed, rather than thought or talked, their way into action. Insofar as multiple features of the situation were perceived through bodily senses, we might say that our sensemaking proceeded from the body.

Struggling with a whirlpool. In a telling episode featured in Findings I, I can be seen struggling but failing to keep our vessel on course. The boat is being pulled firmly to port side, and try as I might, I cannot correct for it, nor do I know what is causing the pull. Not fancying the prospect of being seen to be a wuss (particularly not given that Anton and I were knee-deep into a tiresome battle over our respective places in the pecking order), I push down hard instead with my right leg 
while lightening up on my left, concerned all the while that the asymmetry in power might mess up my back. A sharp pain shooting up the right side of my spine is a tell-tale sign of the risk involved as I continue to drive my oars through the milky water. ${ }^{8}$ My initial suspicion of being caught in a whirlpool isn't supported by the visible evidence: the water looks no different on either side of the boat. I know I am doing everything right and yet it all feels wrong, and so as to keep the bow straight, I have begun to row lopsided, with most of the power directed to my right leg, back and arm, and it is starting to hurt.

I finally swallow my pride and call it out, asking Miguel what side of the river I should be rowing on. He tells me, from inside the cabin, to look for a stronger current. I explain my conundrum: I'm being pulled consistently to one side. My body knew something wasn't right, yet I was unable to identify the source of the problem. Instead of asking for help right away, I put myself at risk of injury in delaying my call as I worried that doing so would affirm what I suspected Anton and Miguel knew all along: that I was the weakest link.

Rowing in tidal waters. Our practice of chasing currents by looking for drifting logs or debris had long since given way to rowing diagonally across the river while comparing GPS speed readings with our felt exertion and attending to small differences in each. As the river widened, this heuristic of crossing the river was the only option left to us to put ourselves in the path of a potentially more favorable current. But, in the final days of the journey, when the river's width came to span several miles, traversing it in search of fast water became unfeasible. Besides, without

\footnotetext{
${ }^{8}$ While rowers talk of "pulling the oars", boat speed is really achieved by pushing down the legs. The arms are a relatively weak muscle group compared to the leg muscles, and to row a boat effectively means to use the hands as hooks, arms straight, holding the oars, while the legs push down. The arms really only ever pull towards the end of a stroke so as to bring the oar into the body before tapping down and straightening the arms again in preparation for the next stroke. Thus, an expression that makes sense in fixed-seat rowing boats has little descriptive currency in the sliding-seat shells used in river rowing.
} 
the shelter of a nearby bank, increasing exposure to wind made for slow progress, and keeping the boat straight forced us to pull on the oars asymmetrically, risking our backs.

We decided to change the schedule to row in alternating, 30-minute spurts to save our backs, before prioritizing rowing together rather than in turns, except at night. Given the river traffic, one of us had to be awake at all times. When the wind was at its worst, and without ever owning up to it except in the privacy provided by our audio journal and my fieldnotes, we would sometimes fold a tee-shirt into a pillow, pull in the oars and rest our heads on them, letting currents do what currents do well. When hitting submerged sandbanks, the only option was deeply unattractive: to jump into the impenetrable river, occasionally sinking knee-deep into the mud, and push the boat out. Piranhas were the least of our worries — the river contained plenty easier prey — the greater risk being that of disturbing a stingray or electric eel. Our fear of the dark invariably gave way to beautiful sunrises, accompanied by grey and pink dolphins playing alongside the boat and ultimately the madness of the cruel midday sun.

Slow progress meant we became increasingly anxious about the possibility of missing our flights home. As Anton upped his codeine-based meds, and as I experimented with ever more creative ways to palliate my posterior, we attended to our moods by changing our GPS to display speed in kilometers rather than miles. Whilst fully aware that we were cheating ourselves, it did give us a false sense of progress.

Just over twenty-four hours before the end of our voyage, having enjoyed a particularly swift current, we hit the wall. Mine had been the last of the three-hour night shifts (from 0300 to 0600) and I was desperate for sleep. Yet Anton, standing on deck and peering into the distance, was convinced there was a tributary, a potential shortcut, some distance downriver. There were boats coming from it and going into it, he said, and persuaded me to forego breakfast and join him on 
the oars for a while longer. What he swore would only take a short while seemed to take forever. The sun was bearing heavily down on our heads, and without nutrition and water, and after five hours of continuous rowing, I began to feel physically sick. My breathing had become shallow and quick, I felt dizzy and unable to formulate a coherent string of words, let alone think. I'd had a strong and persistent pain in the upper left part of my chest, which worried me greatly. The tanks, to rely on a bit of rowing vernacular, were empty. And yet Anton kept calling for more until, at last, after hours of backbreaking work, we capitulated and stopped rowing altogether. We had barely been moving at all, even if the topography suggested we should have been in a relatively fast bit of river. Funny thing is, this bit of river had shown itself to be quick only a few hours ago. We'd been doing everything right.

As we sat licking our wounds, our eyes fixed on the GPS, it appeared we were drifting backwards. Come to think of it, it had felt all along as if we were rowing against, rather than with, the current, but why so? We dropped an anchor to take stock and to decide on a way forward whilst not surrendering any of our hard-won territory. Much of what unfolded next was captured on camera and discussed in Findings I. What is difficult to appreciate from the video footage is the sheer amount of time it took for us to finally latch on to the fact that we might be in a tidal current. With hindsight it is easy to see how a tidal current might explain ever-greater differences in boat speed: hours of momentum cut short by hours of inching along followed by another solid performance in a game of tag. Yet our bodies were simply too exhausted to clue in on the symbols doled out by our GPS and changes in water height with respect to the river bank. Moreover, life on the boat had become so emotionally overloaded and volatile that this affective backdrop likely masked the emotional highs and lows we felt with these rounds of increasingly swift and then slow 
progress, limiting our ability to notice important cues while wasting precious time and resource by proceeding inefficiently along the river's course.

Coping with physical injury. If we take seriously the view that the body has currency in sensemaking, it stands to reason that changes in the body manifest themselves as changes in sensemaking capacity. For example, the constant dousing with water led to "nappy rash" that, in my case, developed into a painful abscess. As the abscess and my discomfort grew, I cut a hole in my rowing seat, figuring that I would be able to continue rowing so long as I fit the sore into the hole. A physician in the UK had meanwhile decided the risk of sepsis was serious and instructed us, via satellite phone, to make an incision and "lance the boil", using surgical equipment procured by a resourceful medical student back home. I chose to forego the anesthetic jab to minimize risk, while Anton readied himself with gloves and a surgical blade. I sourced a clean bit of towel to get my teeth into in preparation for the most unwanted, intimate encounter yet of this voyage. One of our video segments shows Anton plodding away in a medical procedure neither of us is likely to quickly forget (see Photo 7).

--- Insert Photo 7 here ---

While some of the evidence of the body's role in sensemaking plays out immediately, my abscess illustrates how my body's ability to sense-make changes over time. Harsh temperatures had led to dousing which had caused skin damage and laborious skin care practices, an unwelcome bit of amateur surgery, and corresponding modifications to rowing equipment. Courses of action that were once sensible and ought to have maintained our bodily capacities, by keeping us cool enough to row effectively, had unforeseen and ongoing consequences. Significantly, however, exposure to continual physical exertion, repetition of movement, and injury over time did not change each of our bodies in the same way, or to the same extent. Thus, while Miguel and I suffered 
nappy rash, Anton did not, and while Miguel's rash didn't produce anything more serious, mine did, with considerable consequences for my ability to "feel" the water. Making subtle adjustments while rowing (so as to work with, rather than against, the river) was made difficult by the need to maintain a posture such that my abscess would continue to fit my DIY seat. Accordingly, it would be naïve to imagine that this bodily wear and tear was of no consequence in how we made sense of the shifting circumstances of the voyage, where reason itself was fashioned out of these changing particulars of our flesh and blood. And to the extent that reasoning relied on sensory inputs, our bodies were never just in service of the mind. Occasionally, bodies do as bodies will. That is to say, bodies need not "check in" with a mind because they are mindful by definition: unique configurations of achievements and failures, shaped and reshaped through socialization and repeated exposure to, in our case, rowing practice. ${ }^{9}$

\section{DISCUSSION}

We began with the observation that contemporary sensemaking studies overwhelmingly focus on cognition and discourse as the central modes through which people construct meaningful narratives out of ambiguous situations (Maitlis \& Christianson, 2014; Colville et al., 2012; Weick, 2012). Yet sensemaking scholarship has shown surprisingly little interest in the senses (Sandberg \& Tsoukas, 2014). Recent empirical work has begun to redress this by exploring specific aspects of embodiment. For example, visceral and emotional reactions can provide the disruptive cues that trigger sensemaking (Maitlis, 2009), and emotional expressions and physical gestures contribute to how sensemaking unfolds among multiple participants (Cunliffe \& Coupland, 2012; Heaphy,

\footnotetext{
${ }^{9}$ They are also deeply enculturated. To illustrate, upon our arrival in Columbia, and in the spirit of "when in Rome ...", Anton ordered deep-fried larva de palma, a local delicacy. His gagging reflex upon the first bite, and refusal to eat more, is a poignant reminder of just how socialization writes itself into our physical bodies. As the anthropologist Matthew Engelke (2017: 29-32) explains, having been offered a cricket to eat during his fieldwork in Chiweshe, Zimbabwe, his vomiting up the insect was not a "natural" or biological reaction. Rather, his (and Anton's) body reacted as it did because it is deeply enculturated, and in his culture, people don't eat crickets. All the anthropological learning in the world could not undo twenty years of life (2017: 31).
} 
2017). Further, the body plays a role in restricting or forestalling sensemaking. Embodied reactions like pain might block sensemaking because they "narrow attention in various ways" (Maitlis \& Sonenshein, 2010: 573), while intense emotions can restrict people's capacities to make sense (Cornelissen, Mantere \& Vaara, 2014). Among these contributions, the most relevant for our purposes is Cunliffe and Coupland's (2012) exploration of "embodied narrative sensemaking". Based on a film documentary of the 2001 British and Irish Lions [football] tour of Australia, the authors zoom in on a defining incident to foreground the role of intuition and felt bodily interpretations in sensemaking. Their conceptual point of departure is similar to our own: sense is made through the totality of experience (Cunliffe \& Coupland, 2012: 78); occurs in the "lived experience of everyday, ordinary interactions", is temporal and subject to multiple, contested narratives, and is a fully "embodied process of interpretation of self and experience" (Cunliffe \& Coupland, 2012: 64). While sympathetic to their ontological claim and attention to phenomenology, our project offers a different methodology as the basis for a complementary research approach to embodied sensemaking. That is to say, carnal sociology as a bundle of ontological, epistemological and methodological claims (see Methodology II) provides for a particular set of affordances: being able to tune in to how sensemaking felt to one of those involved, we came to understand how sensemaking is mediated by embodied experience.

While the idea of embodiment creates few, if any, real difficulties in everyday life, to parse embodiment into analytically distinct constructs is fiendishly (and famously) complex (cf. Merleau-Ponty, 1968). Lacking a vocabulary, we quickly find ourselves "suspended in hyphens"-mind-body, bio-social, psycho-somatic, socio-material-and typically end up reinforcing the very duality we so wish to transcend (Scheper-Hughes \& Lock, 1987: 10). It is in foregrounding the lived experience in Findings II that we allow "nature, society and culture [to] 
speak simultaneously", where the mindful body is "the most immediate, the proximate terrain where social truths and social contradictions are played out, as well as a locus of personal and social resistance, creativity, and struggle" (Scheper-Hughes \& Lock, 1987: 31).

And it is here that carnal sociology can be helpful in drawing attention to aspects of the human experience that are consequential to it but difficult to access via methodological approaches other than enactive ethnography. Rather than limiting oneself to that which is most easily observable "from the outside looking in" (such as sensorimotor behaviors), enactive ethnography's affordances foreground, in real time, whole body experiences of a particular situation in a particular social and material context "from the inside out". Whatever the merits of "second-order" explorations of sensemaking, these remain of the body, not from it (cf. Gärtner, 2013: 342; Wacquant, 2015). In Table 1, we summarize how a carnal sociological account from the body builds on and departs from both narrative/discursive approaches to sensemaking, and of the body approaches to sensemaking in its core claims and assumptions, methodological approach, and key findings. This table illustrates that many of the core claims and assumptions underpinning a from the body approach are relatively compatible with other approaches to sensemaking. However, the novel affordances of enactive ethnography allow for yet further insights into how the holistic, situated bodied is engaged in sensemaking and what this implies for our understanding of the sensemaking process and its relation to the sensemakers themselves.

--- Insert Table 1 here ---

Below, by contrasting what we see from the video analysis portrayed in Findings I, with what we see using an enactive ethnography in Findings II, we further unpack the promise of carnal sociology as the basis for a from the body research approach to organizational sensemaking. We draw attention to the generative potential of three specific issues: (1) articulating the role and 
importance of the holistic body to how sensemaking arises and proceeds, (2) attending to the "who" of sensemaking, and (3) the broader methodological implications of carnal sociology for organizational sensemaking.

\section{The holistic body in sensemaking}

Following the ontological claim that we are suffering beings of flesh and blood who relate to the world, act in the world, and reflect upon the world using all our available senses, Wacquant offers a set of conceptual handholds to help us explore how body and mind are reciprocally implicated in sensemaking. While we recognize that these handholds are fully entangled with each other, drawing attention to them separately can help us to unpack how they are implicated. For example, sentience is our ability to perceive, to feel pain and joy and fear, and to make sense of subjective sensory experience. Findings II moves beyond the body as a sensory organ to also demonstrate this sentience, or our ability to feel and be conscious of our feelings, and points to our body as the "synthesizing medium" of this sensory muddle (Wacquant, 2015: 3). While our video analysis showed the rowers navigating the Amazon by sensing its currents through their physical bodies, our subsequent carnal account adds far more texture to the felt subjective experience. Anton, Mark and Miguel "felt" as much as "thought" their way across the water, but their sentience also showed up in experiences of fear and worry triggered by near-collisions with river traffic at night, tropical storms, uncertain encounters with locals and bouts of frustration and anger directed at each other. Being confined to a few square feet with no real option to stop and dismount, chronic fatigue, lack of privacy, and continual anxiety around the risk of piracy and collision impacted on their sensemaking. Their crankiness and vigilance (not least with respect to each other) made it difficult to relate to, and empathize with, each other, and to communicate and coordinate efforts. For example, when Mark struggles with the whirlpool, he delays mentioning what he is 
experiencing to the others for fear that he may lose credibility if he does. To the outsider, this incident is shaped by Mark's physical experience of the ambiguous current, the talk that leads to a collective account of what is going on, and a course of action to escape it. But to the one performing the phenomenon, it is shaped by a more holistic experience of being aware of one's place in a petty pecking order with consequences for one's willingness to speak up and ask for help. Balanced against an awareness of physical pain that might signal impending injury, this further risked an already fragile set of circumstances. Thus, the crucible for sensemaking is not simply one in which aspects of the body can be parsed out and foregrounded as consequential. Only the holistic subjective experience and its placement in social, physical and temporal context, can explain where and how sensemaking may unfold.

Beyond sentience, carnal sociology affords an exploration of sensemaking as related to suffering, or the degree to which we feel, absorb, and endure the "threats and blows of the natural and social worlds" (Wacquant, 2015: 3). We could see traces of suffering from our video analysis and surmise how these shaped sensemaking. It was clear that the bodies that arrived in Macapá were different, and differently abled, from those that left Nauta. While the video footage shows Mark's body changing over time with injury, sleep deprivation and lack of nutrition, it never quite captured the lived experience of being that body - an explosive mix of hunger and weariness, of resentment yet neediness, of fear and of wrath — and how that body did what it did because it knew what only it knew, and didn't feel able, or didn't desire, to do otherwise. The rowers at the end of the voyage were substantially thinner and less powerful, sore and therefore unwilling to take certain risks, than those who began it. To be sure, changes to their rowing schedule-a "two-hourson-two-hours-off" giving way to "30-minutes-on-30-minutes-off" and subsequently a decision to row in pairs for blocks of time with the onset of strong headwinds - could be attributed to an 
updating of sense (Christianson, 2019), given that the conditions changed over time and adjustments were made in response to the ambiguity imposed by entering the tidal zone of the river. Yet such an interpretation misses the visceral experience of bodies so physically and emotionally exhausted, and morally defeated, that they endangered themselves further by simply going on.

Our case is perhaps an extreme one in that it foregrounds physical and emotional suffering as an aspect of the holistic embodied experience more prominently than one might encounter in other settings. Nonetheless, it draws attention to the importance of attending holistically to the body in more typical settings for organizational sensemaking. We know from prior work that the body is central to how work gets done in such mainstream settings as investment banks (Michel, 2011; Pérezts, Faÿ, \& Picard, 2015), healthcare organizations (Heaphy, 2017; Hindmarsh \& Pilnick; 2007;) and broadcasting and computer gaming companies (Gylfe, Franck, Lebaron, \& Mantere, 2015; Liu \& Maitlis, 2014). In these settings, using methodological tools of video (primarily), interviews, or shadowing, scholars have shown how bodies communicate nonverbally, transmit emotion and enable coordination, which in turn shapes strategizing and supports collective action (Gylfe et al., 2014; Heaphy, 2017; Hindmarsh \& Pilnick; 2007; Liu \& Maitlis, 2014). In cases where scholars have had direct personal experience, such as Michel's (2011) 9-year ethnographic study of how investment bankers' bodies are shaped by organizational control through socialization, or Perezts et al.'s (2015) study of the embodied collective practices of anti-money laundering analysts, we see more starkly how the moral, relational, and physical aspects of being embodied shape organizational practice. While these latter two studies do not speak directly to sensemaking, they illustrate the potential for a carnal sociology approach to illuminate more 
holistically the aspects of human experience that are so consequential to how work gets done in mainstream organizational settings.

Some settings and circumstances may be particularly amenable to a carnal sociology approach. First, as our data show, longitudinal engagement in an organizational setting affords opportunities to experience how the body changes - physically, emotionally, and relationallyover time, and to potentially trace the cumulative effects on the body (as experiences are sedimented) as well as how these changes alter sensemaking from the body. Studies of longitudinal processes-like socialization and how this relates to sensemaking about one's own identity (Pratt et al., 2006; Petrigrieli, 2011) or an organization's or industry's demands (Michel, 2011)—could be particularly well suited to a carnal sociology. Other longitudinal processes that have been studied from a sensemaking perspective, including changes in identity or identification (Pratt, 2000; Pratt et al., 2006; Vough, 2012) or organizational change processes (Balogun \& Johnson, 2004; Ravasi \& Shultz, 2006; Mantere et al, 2012), could also be productively traced through a carnal sociology approach.

Second, carnal sociology is well suited to studying everyday "immanent" sensemaking (Sandberg \& Touskas, 2015) and how it shapes core organizational processes such as coordination (e.g. Bechky, 2006), performing routines (e.g. Feldman, 2000; Howard-Grenville, 2005), or strategizing (e.g. Kaplan, 2008; Liu \& Maitlis, 2014), for these have been productively studied through attention to the everyday interactions. Finally, carnal sociology can augment our understanding of temporary organizations that rely on "an ever-changing cast of team members, many of whom have never met, to make sense of and work together on a high-stakes, timepressured task" (Maitlis \& Christianson, 2014: 87). Rather than relying on specialized experience, researchers may join others in processes of improvisation in what can be highly unpredictable 
settings. For example, Danner-Schröder and Geiger (2016) studied the enactment of routines in a simulated earthquake recovery training exercise, where the first author experienced how "frequent rehearsals during training sessions ... contributed to an embodiment of the necessary "knowing how" by the team members" (p. 646).

Each of these settings would be ripe for a carnal sociology approach where the holistic embodied experience of participation can help advance scholarship. As Anteby (2013) notes, ethnography is an obvious method for generating insight from one's own experience but the opportunity to use embodied insight "holds true at various degrees for all field researchers and is integral to all research pursuits" (p. 1282). Indeed, Anteby (2013: 1282) cites earlier research to note that: "“'the information obtained, rather than the experience lived, remains the focus of most field-based studies" (Georges and Jones, 1980, p. 3)" There are various ways to capture "the experience lived", as demonstrated in this paper, from video and audio diaries to fieldnotes and photographs. We invite scholars to explore the full extent of these tools in accounting more fully for the explanatory power of "the constitution of sensemakers" on sensemaking itself in a variety of organizational settings (Sandberg \& Tsoukas; 2015: 36).

\section{From the "how" to the "who" in sensemaking}

This leads to a second feature that "from the body" sensemaking attends to: the importance of theorizing the "who" of sensemaking alongside the "how." From its earliest incarnations (e.g., Daft \& Weick, 1984; Weick, 1988; Louis, 1980), the sensemaking literature has focused on explaining how sensemaking is accomplished: through noticing cues, interpreting them and taking action. So pervasive is the focus on the "how" of sensemaking that Maitlis and Christianson (2014) use these three aspects (noticing, interpreting and acting) as the organizing frame for their review of 20 years of the literature. Contemporary debates have elaborated on the "how" of organizational 
sensemaking, for example, by arguing for greater attention to noticing and action, for paying more attention to the flow of sensemaking rather than its triggering through punctuation, and for exploring how updating of already-made sense is accomplished (Christianson, 2017; Rudolph, 2009; Weick, 2010; Sandberg \& Tsoukas, 2015).

Carnal sociology, as shown in Findings II, brings the sensemaker to the foreground. In so doing, it enables us to recognize the way that individual's skills, and their sedimented and situated nature, shapes their capacity to make sense, and the sense that is made. There is a role for biography and individual history in that the "how" of sensemaking can never be understood as inoculated from the "who". People are not interchangeable: it matters that they are capable of doing some things but not others, that they differ in what they can tolerate, that they desire specific people but are unable to stomach others, while yet others cannot stand having them around, or are put off by their smell, demeanor, or the sound of their voice. As Hall (1968) suggested, we cannot assume that people share phenomenological experience; to the contrary, people appear to inhabit distinct sensory worlds and also experience space differently (cf. Low, 2003). These capacities have been "implanted, cultivated and deployed over time through our engagement in the world, [...] gradually deposited in our body as the layered product of our varied individual and collective histories" (Wacquant, 2015: 4; cf. Merleau-Ponty, 1945/1962). They, in turn, shape what a person regards as normal or anomalous, and what she does as a result. As Findings II shows, opportunities for sensemaking arose when Mark and Anton struggled to manipulate the boat due to the Amazon's currents, despite their superior skill as rowers. Their bodies were typical of rowers' bodies - tall, so as to maximize leverage and with strong upper legs, bottoms and core muscles - and their callus formation and ability to generate faster speeds were indicative of years of rowing practice. There were things their bodies knew how to do, and did unthinkingly and without injury, that Miguel's 
took pains to learn. However, Miguel's experience of navigating the Amazon led him to have different embodied skills, such as the ability to read a stretch of water. By contrast, Miguel's body was sinewy, with a strong torso, characteristic of the fighting body. His scars told of the violence his body had witnessed first-hand, in a prior life, and what his body would now tolerate and, by implication, what he would be prepared to do to keep the three of them alive. His experience, therefore, led him to tune into, and respond to, dangers differently from how Mark and Anton would. Mark recalls Miguel's occasional requests for all three to stand on deck, making themselves as large as possible, to warn suspicious-looking others of their physical size and intention to not be intimidated.

Skills and their sedimentation are never purely physical; rather, they embed in cognition and shape it. Recent studies into embodied cognition (see Beilock, 2015) for a useful summary, and Maitlis and Sonenshein (2010) for the relevance of such studies for sensemaking) provide powerful evidence of this. For example, elite tennis players see the net as lower than novices (Witt \& Sugovic, 2010), while elite field-goal kickers perceive the uprights as thicker (Witt \& Dorsch, 2009), and elite dart players targets as larger (Wesp et al., 2004). Conversely, hills look steeper for those out of shape or wearing a backpack (Bhalla \& Proffitt, 1999) or when alone or in the company of someone one dislikes (Schnall et al., 2008), and distances appear up to 30 percent farther away for those with aches or pains (Witt et al., 2009). The sedimentation of the body is therefore not determinate; it is entangled with other aspects of the human experience in the hereand-now. So, while Mark and Anton were able to row efficiently in the best of circumstances, having suffered chronic fatigue and nutritional deficiency, persistent back aches and a painful abscess, their capacity to make sense varied situationally. For example, the hours it took for Anton 
and Mark to finally cue in to the fact that they had been rowing against the tide can only be fully grasped from the perspective of how depleted they were at the time.

The "who" of sensemaking must therefore also be understood as situated, not just within a person's own embodied history, but also temporally, socially, and in physical and cultural space. Just as an individual might detect and act on cues differently based on his skill, sedimentation, and situatedness, these factors may equally lead him to actively ignore opportunities for sensemaking. For example, the physical space available on board to rest and recuperate, to reflect and react, was severely curtailed. As noted briefly in Findings II, interpersonal conflicts typically happened when the threesome had to moor up to check in with the Navy in major towns along the route. This is conceivably because it is easier to walk away from conflict when not confined to a boat in the middle of a river and surrounded by jungle. Thus, the rowers will have self-censored when on board, ignoring opportunities to discursively make sense, given the potentially serious consequence of falling out. ${ }^{10}$

Shifting greater attention to the "who" of sensemaking is consistent with perspectives that situate organizational life (Feldman \& Orlikowski, 2011), and demonstrate that people are not interchangeable in how they, for example, perceive problems (Bechky, 2003), perform routines (Howard-Grenville, 2005), or engage with technologies (Orlikowski, 1996). Accordingly, it can show how accounting for specific people in specific circumstances shapes the actual process of sensemaking. Specific people, of course, have always been present in accounts of sensemaking, even if the import of their embodied, sedimented, and situated skills were rarely ever made explicit. For example, Whiteman and Cooper's (2010) account of how Whiteman's lack of embeddedness

\footnotetext{
${ }^{10}$ Mark remembers talking to submariners during his fieldwork in a field hospital in Helmand (de Rond, 2017; de Rond, 2016), where those having spent 3 months confined to a submarine would often comment on how little conflict there was during that period, only for it to crop up when back on shore. They explained that one simply could not afford to have all-out conflicts on a submarine given the limited space available.
} 
in the harsh Canadian subarctic led to her slipping and falling into a river, risking drowning and hypothermia, is illuminating for suggesting that the person doing the sensemaking can be hugely (and so nearly fatally) consequential for the sense that is made. By contrast, Whiteman's informant, a Cree trapper who had lived his entire life in the subarctic and was physically differently endowed, made different sense of ecological cues that Whiteman missed, and ensured her survival.

Beyond seeing how cues for sensemaking are in part shaped by who the sensemaker is, and how she arrived at the situated sensemaking occasion, paying attention to the "who" invites new ways of seeing the temporality, pacing, and path dependency of sensemaking. Sensemaking is often taken as occurring in fleeting moments, difficult to capture except in retrospect, and this may be one reason why so many contemporary sensemaking studies focus on interpretation at the expense of attending to the processes of noticing and acting. Weick himself noted (1995: 49) that "sensemaking tends to be swift, which means we are more likely to see products than processes." This may be particularly true when we have the capacity to only see sensemaking from the outside. But from the perspective of Wacquant's carnal sociology, what leads in to any given sensemaking episode is the embodied and lived histories of prior ones (or prior opportunities for making sense untaken, due to petty disagreements, grumpiness, exhaustion, or real or imagined relational dramas). Carnal sociology shows how being thusly situated does not lend itself to neatly parsed stimulus-response patterns that might give parsimonious (but often misleading) cues to sensemaking triggers and actions. Indeed, carnal sociology shows us that the situatedness of action involves both the embodied present and past, or the totality of the experiences that shape how we show up.

Again, these observations have implications for more typical organizational settings. Indeed, much of the sensemaking literature notes the importance of situatedness to the triggering of 
sensemaking and how it unfolds, in the sense that the particular nature of a crisis and its timing (Christianson, et al., 2009), or the nature of a threat to the organization's collective identity (Elsbach \& Kramer, 1996; Ravasi \& Schultz, 2006), or the way in which an organizational change initiative is handled (Mantere, Schildt, \& Sillince, 2012) matters greatly to how people react and make sense. Thus, the broader call for us to better explore how the "constitution of sensemakers" (Sandberg \& Touskas, 2015:36) comes into play urges us to pay attention to different embodied endowments and experiences that people enter sensemaking situations with, and how these may be privileged or suppressed given situational features, interpersonal dynamics, or broader patterns of cultural and power relations around such factors as gender, race, age or ethnicity.

Finally, we caution that the "who" of sensemaking not be taken as the atomized individual. As carnal sociology and our findings show, the embodied experience of sensemaking is always in relation to one's social situation and the relationships (and their histories) in which one is entangled. To this end, we do not deny that sensemaking is inherently social, but we insist that to understand how it plays out intersubjectively, we need to go beyond the current overwhelming attention to discourse and language as the medium of sensemaking. As Maitlis and Christianson (2014: 81) observe in their review: "in most current writing, organizational sensemaking is more often understood as fundamentally concerned with language". But in any organizational setting people also carry into sensemaking opportunities a host of relational baggage, which, for better or worse and no less so than on a boat in the Amazon, will shape their willingness to trust others' experiences, their proclivity to speak up or stay silent about their own, or the lengths they will go to in support or denial of a course of action. For these reasons, Wacquant's carnal sociology can bring new ways of seeing how sensemaking unfolds from the body, and through the body's engagement in social settings, which are inherently entangled with the sentience, suffering, skills, 
sedimentation, and situatedness of being a human body, in any organizational setting, typical or otherwise.

\section{Some methodological challenges}

We close with a reflection on the methodological challenges of using carnal sociology to further explore the embodied experience of organizational sensemaking. Performing the phenomenon calls on researchers to experience the sensations, skills, and situated actions of their informants. Clearly, in some settings this will prove difficult (e.g., as a member of a trauma surgical team when not medically trained). However, as Wacquant (2015: 5) observes:

it is not always easy and straightforward to gain access to and perform on the target social scene: becoming an active member often takes time, having special qualities, or obtaining certification. You may just not possess the sang-froid needed to be a police officer or the litheness to be a ballerina, you cannot hope to become a judge on short order, and you will hopefully not be authorized to perform brain surgery at a top hospital for purposes of sociological understanding. But you could well become a props technician for the ballet, sign up as an intern with pretrial services, or work as an orderly in the operating ward. There are always multiple doors onto any stage.

In certain settings, being a novice performing the phenomenon will be an advantage, for it can open researchers up to important new insights, especially if they work alongside those already skilled in the setting and use their experience to gain greater insight into the bodily skills and sedimentation that enable sensemaking. The limitations of studying settings where one might perform the phenomenon are also opportunities, for they likely put the researcher in position to capture the more mundane day-to-day sensemaking of people responding to their unfolding circumstances (Sandberg \& Tsoukas, 2015). The chances of being in the right place at the right time to capture sensemaking following a major disaster are low through this mode of research. Nonetheless, this can help correct for the sensemaking literature's overreliance on archival data and formal interviews that reveal largely retrospective interpretations. Wacquant reminds us that 
carnal sociology is applicable anywhere, not limited to the "extremes of society... or situations of risk and urgency" but as "a general approach to social life because all agents are embodied and all social life rests on a bedrock of visceral know-how" (2005: 466-7).

Carnal sociology can also enhance other forms of data collection and analysis. In our case, the access to 755 video segments, 62 audio journals, fieldnotes and interviews, enabled us to generate an account of sensemaking (Findings I) that helped us draw out differences in the enactive account (Findings II). Watching and re-watching the video helped us see and occasionally pick out details that Mark was unable to recall when interviewed (such as Anton's warning of the risks of dousing oneself). However, the authors who did not perform the phenomenon were obviously far less able to relate to the embodied experience that the video footage, audio journal and fieldnotes were there to convey. Despite working for years on these data, there are aspects of Mark's account that two of the authors still found surprising and deeply illuminating as he put on the page what it really felt like. In fact, in writing Findings II, Mark noticed how the strong emotions of that time-and the anxiety, resentment and shame in particular-began once again to course through his arteries, even a full 5 years after pushing off from Peru. Ethnography never really leaves the body.

A final challenge stems from the difficulty we have, as humans, and as researchers wedded to text as our way of reporting, in representing "being a lived body". Our failure to do full justice to embodiment - to provide readers with a "here's what it really all felt like" remains the least satisfactory part of this paper. As Heaphy, Locke and Booth (2014: pp 61) note: "writing about embodiment in a way that does not begin in the head is a real challenge; bringing the body forward in a way that represents the full expressive potential of the body (Michel, 2011; Quaeghebur, 2012) is working against habit of separating the mind and body and subjugating the body under the mind." To address this challenge, we adopted a different writing style in Findings II to give 
stronger voice to corporeal experience and foreground its role in sensemaking. In enactive ethnography, the self is the principal means by which we come to understand a community, process, phenomenon or situation, and while the self isn't ever the point of inquiry, an ethnography may be more or less effective depending on choices of voice, style and the representation of self and others (cf. Goodall, 2010). Wacquant's (2005) Body and Soul, for example, showcases the power of a first-person account from the body that also relies on colloquialisms and lingua franca. We encourage researchers to continue to explore additional means of exploring and communicating embodied organizational phenomenon.

\section{CONCLUSION}

By way of an enactive ethnography of a first-ever attempt to scull the length of the navigable Amazon, this paper developed a way of seeing sensemaking as unfolding from the body. This account of sensemaking attends to how the body is sensate, skilled, sedimented, situated and capable of suffering. While prior work on embodied sensemaking suggests how having a body influences the cues and processes involved, Wacquant's carnal sociology enabled us to generate a more holistic account of how being a body is fully entangled with sensemaking. As with any attempt to introduce a "new way of seeing", this approach needs kicking around but, we hope, has genuine promise to advance our understanding of sensemaking as deeply embodied, and as profoundly tied to the experience of flesh-and-blood fellow travelers. 


\section{REFERENCES}

Abolafia, M. Y. 2010. Narrative construction as sensemaking: How a central bank thinks. Organization Studies, 31(3): 349-367.

Anteby, M. 2013. Relaxing the taboo on telling our own stories: Upholding professional distance and personal involvement. Organization Science, 24(4), 1277-1290.

Balogun, J., \& Johnson, G. 2004. Organizational restructuring and middle manager sensemaking. Academy of Management Journal, 47(4): 523-549.

Bechky, B. A. 2003. Sharing meaning across occupational communities: The transformation of understanding on a production floor. Organization science, 14(3), 312-330.

Bechky, B. A. 2006. Gaffers, gofers, and grips: Role-based coordination in temporary organizations. Organization science, 17(1), 3-21.

Becker, E. 1973. The denial of death. New York: Free Press.

Beilock, S., 2015. How the body knows its mind: The surprising power of the physical environment to influence how you think and feel. Simon and Schuster.

Bigley, G. A., \& Roberts, K. H. 2001. The incident command system: High-reliability organizing for complex and volatile task environments. Academy of Management Journal, 44(6), 12811299.

Bhalla, M., \& Proffitt, D. R. (1999). Visual-motor recalibration in geographical slant perception. Journal of Experimental Psychology: Human Perception and Performance, 25(4), 1076-1096.

Bourdieu, P. 1977. Outline of a theory of practice. Cambridge, UK: Cambridge University Press

Bourdieu, P. 1990. The logic of practice. Stanford University Press.

Bourdieu, P. 2000. Pascalian meditations. Stanford University Press.

Christianson, M. K. 2019. More and Less Effective Updating: The Role of Trajectory Management in Making Sense Again. Administrative Science Quarterly,

Christianson, M.K. 2018. Mapping the terrain: The use of video-based research in top-tier organizational journals. Organizational Research Methods. 261-287.

Christianson, M. K., Farkas, M. T., Sutcliffe, K. M., \& Weick, K. E. 2009. Learning through rare events: Significant interruptions at the Baltimore \& Ohio Railroad Museum. Organization Science, 20(5), 846-860.

Clark, A., 1998. Being there: putting brain, body, and world together again. Cambridge, MA: MIT Press. 
Corley, K. G., \& Gioia, D. A. 2004. Identity ambiguity and change in the wake of a corporate spinoff. Administrative Science Quarterly, 49(2): 173-208.

Cornelissen, J. P., Mantere, S., \& Vaara, E. 2014. The contraction of meaning: The combined effect of communication, emotions, and materiality on sensemaking in the Stockwell shooting. Journal of Management Studies, 51(5): 699-736.

Csordas, T. 1994. Embodiment and experience. Cambridge, UK: Cambridge University Press.

Cunliffe, A., \& Coupland, C. 2012. From hero to villain to hero: Making experience sensible through embodied narrative sensemaking. Human Relations, 65(1): 63-88.

Daft, R. L., \& Weick, K. 1984. Toward a Model of Organizations as Interpretation Systems. Academy of Management Review, 9(2): 284-295.

Dall'Alba, G., Sandberg, J. and Sidhu, R.K. 2017 Embodying skillful performance: co-constituting body and world in biotechnology, Educational Philosophy and Theory, https://doi.org/10.1080/00131857.2017.1343114

Damasio, A. 1999. The feeling of what happens: Body and emotion in the making of consciousness. Mariner Books.

Damasio, A. 2012. Self comes to mind: Constructing the conscious brain. Vintage.

de Rond, M. 2017. Doctors at war: Life and death in a field hospital. Cornell University Press

de Rond, M. \& Lok, J. 2016. Some things can never be unseen: the role of context in psychological injury at war. Academy of Management Journal

de Rond, M. 2008. The last amateurs: To hell and back with the Cambridge boat race crew. London: Icon Books

Desmond, M. 2008. On the fireline: Living and dying with wildland firefighters. University of Chicago Press.

Dougherty, D. S., \& Drumheller, K. 2006. Sensemaking and emotions in organizations: Accounting for emotions in a rational(ized) context. Communication Studies, 57: 215-238.

Drazin, R., Glynn, M.A. and Kazanjian, R.K., 1999. Multilevel theorizing about creativity in organizations: A sensemaking perspective. Academy of Management Review, 24(2), pp.286307.

Ekman, P. 1992. Facial expressions of emotion: New findings, new questions. Psychological Science, 3: 34-38.

Engelke, M., 2017. How to think like an anthropologist. London: Penguin.

Elsbach, K. D., Barr, P. S., \& Hargadon, A. B. 2005. Identifying situated cognition in organizations. Organization Science, 16(4): 422-433. 
Feldman, M. S. 2000. Organizational routines as a source of continuous change. Organization Science, 11(6), 611-629.

Feldman, M. S., \& Orlikowski, W. J. 2011. Theorizing Practice and Practicing Theory. Organization Science, 22(5): 1240-1253. http://doi.org/10.1287/orsc.1100.0612

Foucault, M. 1977. Discipline and punishment. New York, NY: Random House.

Gärtner, C. 2013. Cognition, knowing and learning in the flesh: Six views on embodied knowing in organization studies. Scandinavian Journal of Management, 29(4): 338-352.

Giddens, A. 1986. The constitution of society: Outline of the theory of structuration (Vol. 349). University of California Press.

Gioia, D. A., Corley, K. G., \& Hamilton, A. L. 2013. Seeking qualitative rigor in inductive research: Notes on the Gioia methodology. Organizational Research Methods, 16(1): 15-31.

Gioia, D.A. and Thomas, J.B., 1996. Identity, image, and issue interpretation: Sensemaking during strategic change in academia. Administrative science quarterly, pp.370-403.

Grosz, E. 1994. Volatile bodies: Toward a corporeal feminism. Indiana University Press.

Gylfe, P., Franck, H., Lebaron, C., \& Mantere, S. 2016. Video methods in strategy research: Focusing on embodied cognition. Strategic Management Journal, 37(1), 133-148.

Hall, E.T. 1968. Proxemics. Current Anthropology, 9(2): 83-95

Hällgren, M., Rouleau, L. and de Rond, M., 2018. A matter of life or death: How extreme context research matters for management and organization studies. Academy of Management Annals, 12(1), pp.111-153.

Harquail, C. V., \& Wilcox King, A. 2010. Construing organizational identity: The role of embodied cognition. Organization Studies, 31(12): 1619-1648.

Harrison, S. H., \& Rouse, E. D. 2014. Let's dance! Elastic coordination in creative group work: A qualitative study of modern dancers. Academy of Management Journal, 57(5), 1256-1283.

Heaphy, E. D. 2007. Bodily insights: Three lenses on positive organizational relationships. In J. E. Dutton \& B. R. Ragins (Eds.), Exploring positive relationships at work: Building a theoretical and research foundation: 47-71. Psychology Press.

Heaphy, E. D., 2017. "Dancing on Hot Coals": How Emotion Work Facilitates Collective Sensemaking. Academy of Management Journal, 60(2), pp.642-670.

Heaphy, E. D., \& Dutton, J. E. 2008. Positive social interactions and the human body at work: Linking organizations and physiology. Academy of Management Review, 33(1): 137-162.

Heaphy, E.D., Locke, K. and Booth, B., 2016. Embodied relational competence: Attending to the body in the boundary-spanning work of patient advocates. In Qualitative Organizational 
Research: Best papers from the Davis Conference on Qualitative Research (Vol. 3, pp. 161197). Charlotte, NC: Information Age Publishing.

Heath, C., J. Hindmarsh, P. Luff. 2010. Video in qualitative research: Analysing social interaction in everyday life. Sage, London.

Hindmarsh, J., \& Pilnick, A. 2007. Knowing bodies at work: Embodiment and ephemeral teamwork in anaesthesia. Organization Studies, 28(9): 1395-1416.

Hindmarsh, J., N. Llewellyn. 2018. Video in sociomaterial investigations: A solution to the problem of relevance for organizational research. Organizational Research Methods. 412437.

Hochschild, A. R. 2012. The managed heart: Commercialization of human feeling. University of California Press

Holmes, S. 2013. Fresh fruit, broken bodies: Migrant farmworkers in the United States (Vol. 27). Univ of California Press.

Howard-Grenville, J. A. 2005. The persistence of flexible organizational routines: The role of agency and organizational context. Organization Science, 16(6), 618-636.

Ingold, T., 2011. Being alive: Essays on movement, knowledge and description. Routledge.

Kaplan, S. 2008. Framing contests: Strategy making under uncertainty. Organization Science, 19(5), 729-752.

Keltner, D., \& Haidt, J. 1999. Social functions of emotions at four levels of analysis. Cognition and Emotion, 13: 505-521.

Jarzabkowski, P., Bednarek, R., \& Cabantous, L. 2015. Conducting global team-based ethnography: Methodological challenges and practical methods. Human Relations, 68(1), 333 .

Ketokivi, M., \& Mantere, S. 2010. Two strategies for inductive reasoning in organizational research. Academy of Management Review, 35(2): 315-333.

Lakoff, G., 2008. Women, fire, and dangerous things. University of Chicago press.

Lakoff, G. and Johnson, M., 1999. Philosophy in the flesh. New york: Basic books.

Lakoff, G. and Johnson, M., 2008. Metaphors we live by. University of Chicago press.

Lakoff, G. and Núñez, R.E., 2000. Where mathematics comes from: How the embodied mind brings mathematics into being. $\boldsymbol{A M C}, 10(12)$, pp.720-733. 
LeBaron, C. D., \& Jones, S. E. 2002. Closing up closings: Showing the relevance of the social and material surround to the completion of interaction. Journal of Communication, 52(3), 542565.

Liu, F., \& Maitlis, S. 2014. Emotional dynamics and strategizing processes: A study of strategy conversations in top team meetings. Journal of Management Studies, 51(2), 202-234.

Locke, K., \& Golden-Biddle, K. 1997. Constructing Opportunities for Contribution: Structuring Intertextual Coherence and "Problematizing" in Organization Studies. Academy of Management Journal, 40(5): 1023-1062.

Low, S.M. 2003. Embodied space(s): anthropological theories of body, space and culture. Space \& Culture, 6(1): 9-18

Lüscher, L. S., \& Lewis, M. W. 2008. Organizational change and managerial sensemaking: Working through paradox. Academy of Management Journal, 51(2): 221-240.

Maitlis, S. 2005. The social processes of organizational sensemaking. Academy of Management Journal, 48(1): 21-49.

Maitlis, S. 2009. Who am I now? Sensemaking and identity in posttraumatic growth. In L. M. Roberts \& J. E. Dutton (Eds.). Exploring positive identities and organizations: Building a theoretical and research foundation: 47-76. Psychology Press.

Maitlis, S., \& Christianson, M. 2014. Sensemaking in Organizations: Taking stock and moving forward. The Academy of Management Annals, 8(1): 57-125. http://doi.org/10.1080/19416520.2014.873177

Maitlis, S., \& Lawrence, T. B. 2007. Triggers and enablers of sensegiving in organizations. Academy of Management Journal, 50(1): 57-84.

Maitlis, S., \& Sonenshein, S. 2010. Sensemaking in crisis and change: Inspiration and insights from Weick (1988). Journal of Management Studies, 47(3): 551-580.

Mantere, S., \& Ketokivi, M. 2013. Reasoning in organization science. Academy of Management Review, 38(1): 70-89.

Mantere, S., Schildt, H. A., \& Sillince, J. A. A. 2012. Reversal of strategic change. Academy of Management Journal, 55(1), 172-196.

McNerney, S. 2011. A brief guide to embodied cognition: why you are not your brain. Scientific American. https://blogs.scientificamerican.com/guest-blog/a-brief-guide-to-embodiedcognition-why-you-are-not-your-brain/ (last accessed: 22 Feb 2019)

Merleau-Ponty, M. 1945/1962. Phenomenology of perception (C. Smith, Trans.). London: Routledge \& Kegan Paul. 
Merleau-Ponty, M. 1968. The visible and the invisible: Followed by working notes. Northwestern University Press.

Michel, A. 2011. Transcending socialization: A nine-year ethnography of the body's role in organizational control and knowledge workers' transformation. Administrative Science Quarterly, 56(3), 325-368.

Orlikowski, W. J. 1996. Improvising organizational transformation over time: A situated change perspective. Information Systems Research, 7(1), 63-92

Pachirat, T. 2011. Every twelve seconds: Industrialized slaughter and the politics of sight. Yale University Press.

Pérezts, M., Faÿ, E., \& Picard, S. 2015. Ethics, embodied life and esprit de corps: An ethnographic study with anti-money laundering analysts. Organization, 22(2), 217-234.

Petriglieri, J. L. 2011. Under threat: Responses to and the consequences of threats to individuals' identities. Academy of Management Review, 36(4), 641-662.

Pratt, M. 2000. The good, the bad, and the ambivalent: Managing identification among Amway distributors. Administrative Science Quarterly, 45(3): 456-493.

Pratt, M. G., Rockmann, K. W., \& Kaufmann, J. B. 2006. Constructing professional identity: The role of work and identity learning cycles in the customization of identity among medical residents. Academy of Management Journal, 49(2): 235-262.

Purser, G. 2009. The dignity of job-seeking men: Boundary work among immigrant day laborers. Journal of Contemporary Ethnography, 38(1): 117-139.

Ravasi, D., \& Schultz, M. 2006. Responding to organizational identity threats: Exploring the role of organizational culture. Academy of management journal, 49(3), 433-458.

Romero, S. 2016. 'There's No Law on the Amazon': River Pirates Terrorize Ships by Night. The New York Times, https://www.nytimes.com/2016/11/19/world/americas/brazil-amazonpirates-riverboats-rain-forest.html. Last accessed: 22-09-2018

Rouleau, L., \& Balogun, J. 2011. Middle managers, strategic sensemaking, and discursive competence. Journal of Management Studies, 48(5): 953-983.

Sandberg, J., \& Tsoukas, H. 2015. Making sense of the sensemaking perspective: Its constituents, limitations, and opportunities for further development. Journal of Organizational Behavior, 36(S1), S6-S32. http://doi.org/10.1002/job.193

Scheper-Hughes, N., \& Lock M. M. 1987. The mindful body: A prolegomenon to future work in medical anthropology. Medical anthropology quarterly, 1(1): 6-41. 
Schnall, S., Harber, K.D., Stefanucci, J.K. and Proffitt, D.R., 2008. Social support and the perception of geographical slant. Journal of Experimental Social Psychology,44(5), pp.1246-1255.

Shapiro, L. 2010. Embodied cognition. Routledge.

Sheets-Johnstone, M. 1999. The primacy of movement. Amsterdam: John Benjamins Publishing.

Sonenshein, S. 2010. We're Changing - Or are we? Untangling the role of progressive, regressive, and stability narratives during strategic change implementation. Academy of Management Journal, 53(3): 477-512.

Starbuck, W. H., \& Milliken, F. J. 1988. Executives' perceptual filters: What they notice and how they make sense. Unpublished Manuscript.

Stigliani, I., \& Ravasi, D. 2012. Organizing thoughts and connecting brains: Material practices and the transition from individual to group-level prospective sensemaking. Academy of Management Journal, 55(5): 1232-1259. http://doi.org/10.5465/amj.2010.0890

Streeck, J., Goodwin, C. and LeBaron, C., 2011. Embodied Interaction: Language and Body in the Material World. Cambridge University Press.

Thomas, J., Clark, S., \& Gioia, D. 1993. Strategic Sensemaking and Organizational Performance: Linkages among Scanning, Interpretation, Action, and Outcomes. Academy of Management Journal, 36(2): 239-270.

Trevor-Roper, H., 2014. The secret world: behind the curtain of British intelligence in World War II and the Cold War. IB Tauris.

Turner, B.S. 1984. The body and society. London: Basil Blackwell.

Van der Kolk, B., 2014. The body keeps the score: Mind, brain and body in the transformation of trauma. Penguin UK.

Van Maanen, J. (2010). Ethnography as work: Some rules of engagement. Journal of Management Studies, 48(1), 218-234.

Vough, H. 2012. Not all identifications are created equal: Exploring employee accounts for workgroup, organizational, and professional identification. Organization Science, 23(3), 778800 .

Wacquant, L. 1995a. Pugs at Work: Bodily Capital and Bodily Labour among Professional Boxers. Body \& Society, 1(1): 65-93. http://doi.org/10.1177/1357034X95001001005

Wacquant, L. 1995b. The pugilistic point of view: How boxers think and feel about their trade. Theory and Society, 24(4): 489-535.

Wacquant, L. 2004. Body \& soul. Oxford: Oxford University Press. 
Wacquant, L. 2005. Carnal Connections: On Embodiment, Apprenticeship, and Membership. Qualitative Sociology, 28(4): 445-474. http://doi.org/10.1007/s11133-005-8367-0

Wacquant, L. 2011. Habitus as topic and tool: Reflections on becoming a prizefighter. Qualitative Research in Psychology, 8(1): 81-92.

Wacquant, L., 2014a. Homines in extremis: What fighting scholars teach us about habitus. Body \& Society, 20(2), pp.3-17.

Wacquant, L., 2014b. Putting habitus in its place: Rejoinder to the symposium. Body \& Society, 20(2), pp.118-139.

Wacquant, L. 2015. For a sociology of flesh and blood. Qualitative Sociology, 38(1): 1-11. http://doi.org/10.1007/s11133-014-9291-y

Wacquant, L. 2018. The triple specificity of carnal sociology. Unpublished paper (on file with the author)

Weick, K. 1993. The Collapse of Sensemaking in Organizations: The Mann Gulch Disaster. Administrative Science Quarterly, 38(4): 628-652.

Weick, K. E. 1995. Sensemaking in organizations (Foundations for organizational science). Thousand Oaks: Sage Publications Inc.

Weick, K. E. 2009. 6a Enacting an Environment: The Infrastructure of Organizing. In R. Westwood \& S. Clegg (Eds.) Debating Organization: Point-Counterpoint in Organization Studies: 184-194. John Wiley \& Sons.

Weick, K.E., 2010. Reflections on enacted sensemaking in the Bhopal disaster. Journal of Management Studies, 47(3), pp.537-550.

Weick, K., Sutcliffe, K. M., \& Obstfeld, D. 2005. Organizing and the Process of Sensemaking. Organization Science, 16(4): 409-421.

Wesp, R., Cichello, P., Gracia, E.B. et al. Perception \& Psychophysics (2004) 66: 1261.

Whiteman, G., \& Cooper, W. H. 2011. Ecological Sensemaking. Academy of Management Journal, 54(5): 889-911. http://doi.org/10.5465/amj.2008.0843

Witt, J.K. \& Dorsch, T.E. 2009. Kicking to bigger uprights: field goal kicking performance influences perceived size. Perception. Vol 38, Issue 9, pp. 1328 - 1340

Witt, J.K., Linkenauger, S.A., Bakdash, J.Z. et al. Experimental Brain Research (2009) 192: 145. https://doi.org/10.1007/s00221-008-1594-3

Witt, J.K., Schuck, D.M. \& Taylor, J.E. 2011. Action-specific effects underwater. Perception. Vol 40, Issue 5, pp. 530 - 537 
Witt, J.K. \& Sugovic, M. 2010. Performance and ease influence perceived speed. Perception. Vol 39, Issue 10, pp. $1341-1353$

Young, I. M. 1990. Throwing like a girl: A phenomenology of body comportment, motility, and spatiality. In I.M. Young, Throwing like a girl and other essays in feminist philosophy and social theory: 141-159. Bloomington: Indiana University Press. 
Table 1: Comparing and contrasting approaches to sensemaking

\begin{tabular}{|c|c|c|c|}
\hline & $\begin{array}{c}\text { Narrative/Discursive Approach to } \\
\text { Sensemaking }\end{array}$ & "Of the body" Approach to Sensemaking & "From the body" Approach to Sensemaking \\
\hline $\begin{array}{l}\text { Core claims/ } \\
\text { assumptions }\end{array}$ & $\begin{array}{l}\text { - Sensemaking is a process that unfolds through } \\
\text { noticing or bracketing cues, interpreting them, } \\
\text { and taking action. } \\
\text { - Sensemaking is social and is "constructed in } \\
\text { language and shared through narrative" (Maitlis } \\
\text { \& Christianson, 2014: 99). } \\
\text { - Sensemaking is "an ongoing process in which } \\
\text { provisional understandings are constantly } \\
\text { adjusted in response to new information or } \\
\text { changing circumstances" (Christianson, 2019), } \\
\text { which involves the "redrafting of an emerging } \\
\text { story so that it becomes more comprehensive" } \\
\text { (Weick, Sutcliffe, and Obstfeld, 2005: 415). }\end{array}$ & $\begin{array}{l}\text { - Sensemaking is a process that also unfolds through } \\
\text { the embodied experience of ongoing everyday } \\
\text { interactions (Cunliffe \& Coupland, 2011; Sandberg \& } \\
\text { Tsoukas, 2015). } \\
\text { - Sensemaking is experiential in that "we make life } \\
\text { sensible through our lived, felt bodily experiences and } \\
\text { 'sensing' of our surroundings." (Cunliffe \& Coupland, } \\
\text { 2011: 68) } \\
\text { - Sensemaking need not only be episodic but can occur } \\
\text { as "a mode of engagement whereby actors ... } \\
\text { spontaneously respond to the developing situation at } \\
\text { hand." (Sandberg \& Tsoukas, 2015: 20) }\end{array}$ & $\begin{array}{l}\text { - Core claims and assumptions consistent with those } \\
\text { in "of the body" and "narrative and discursive" } \\
\text { approaches to sensemaking, plus: } \\
\text { o Sensemaking is situated in the body's } \\
\text { individual history as well as in its social, } \\
\text { relational, and cultural context. } \\
\text { o Sensemaking may be episodic or ongoing but } \\
\text { in each case is informed by the holistic } \\
\text { experience of being a body (interacting with } \\
\text { other bodies) in that setting. }\end{array}$ \\
\hline $\begin{array}{l}\text { Methodological } \\
\text { approach }\end{array}$ & $\begin{array}{l}\text { - Data sources include text or talk captured } \\
\text { through archival material (e.g., Cornelissen et } \\
\text { al., 2014) interviews (e.g., Maitlis, 2005) and/or } \\
\text { observation (e.g., Gioia \& Chittipeddi, 1991). } \\
\text { - Analysis is focused on the sequence of and } \\
\text { meanings ascribed to events or new } \\
\text { information. }\end{array}$ & $\begin{array}{l}\text { - Data sources include text, talk, gestures, bodily } \\
\text { orientations, emotions, and/or material cues captured } \\
\text { through archival video (e.g., Cunliffe \& Coupland, } \\
\text { 2011) proprietary video (e.g., Liu \& Maitlis, 2014; } \\
\text { Christianson, 2019; our 'of the body' account), and/or } \\
\text { nonparticipant observation (e.g., Heaphy, 2017). } \\
\text { - Analysis of sensorimotor responses, interactions with } \\
\text { other people, and expressed emotion in relation to } \\
\text { unfolding circumstances. }\end{array}$ & $\begin{array}{l}\text { - Data sources include first-person experience of } \\
\text { performing the phenomenon of interest; video, } \\
\text { audio and fieldnotes can be used as memory aids } \\
\text { inasmuch as they record aspects of the experience } \\
\text { as it unfolds (e.g., our data; Whiteman \& Cooper, } \\
\text { 2011). } \\
\text { - Analysis of sensorimotor experiences, relational } \\
\text { tone, and felt emotion in relation to unfolding } \\
\text { circumstances; enabled by the analytical handholds } \\
\text { of carnal sociology (Wacquant, 2015) that we are } \\
\text { "sensate, suffering, skilled, sedimented, and } \\
\text { situated corporeal creatures." }\end{array}$ \\
\hline Key Findings & $\begin{array}{l}\text { - Sensemaking inheres in shared } \\
\text { meaning/interpretations that perpetuate or are } \\
\text { periodically revised. (Weick, Sutcliffe, \& } \\
\text { Obstfeld, 2005; Christianson, 2019) } \\
\text { - Emotions and the material environment enter in } \\
\text { to sensemaking inasmuch as they trigger or } \\
\text { forestall it, or aid in the construction of sense } \\
\text { through discourse. (Maitlis, 2009; Cornelissen } \\
\text { et al., 2014) }\end{array}$ & $\begin{array}{l}\text { - Expressing and displaying emotion mediates collective } \\
\text { sensemaking. (Heaphy, 2017) } \\
\text { - Bodily movements - including "verbal and facial } \\
\text { expressions and body gestures ... convey the intensity } \\
\text { of [peoples'] emotions and play into their attempts to } \\
\text { make [a] situation sensible." (Cunliffe \& Coupland, } \\
\text { 2011: 80) } \\
\text { - Sensemaking appears to draw on "intuitive and } \\
\text { informed feeling in [the] body" (Cunliffe \& Coupland, } \\
\text { 2011: } 77 \text {; and in our video data of chasing currents), } \\
\text { though this is observed by the analyst, not directly } \\
\text { experienced. }\end{array}$ & $\begin{array}{l}\text { - Sensemaking unfolds from the holistic experience } \\
\text { of being a body, including sensory experience } \\
\text { entangled with emotional, physical, relational and } \\
\text { moral aspects. } \\
\text { - A person's capacity for and engagement in } \\
\text { sensemaking is shaped by their embodied } \\
\text { experience and history, not only by the situation. } \\
\text { i.e., the 'who' of sensemaking matters to how it } \\
\text { unfolds. (e.g., our data; Whiteman \& Cooper, 2011). }\end{array}$ \\
\hline
\end{tabular}




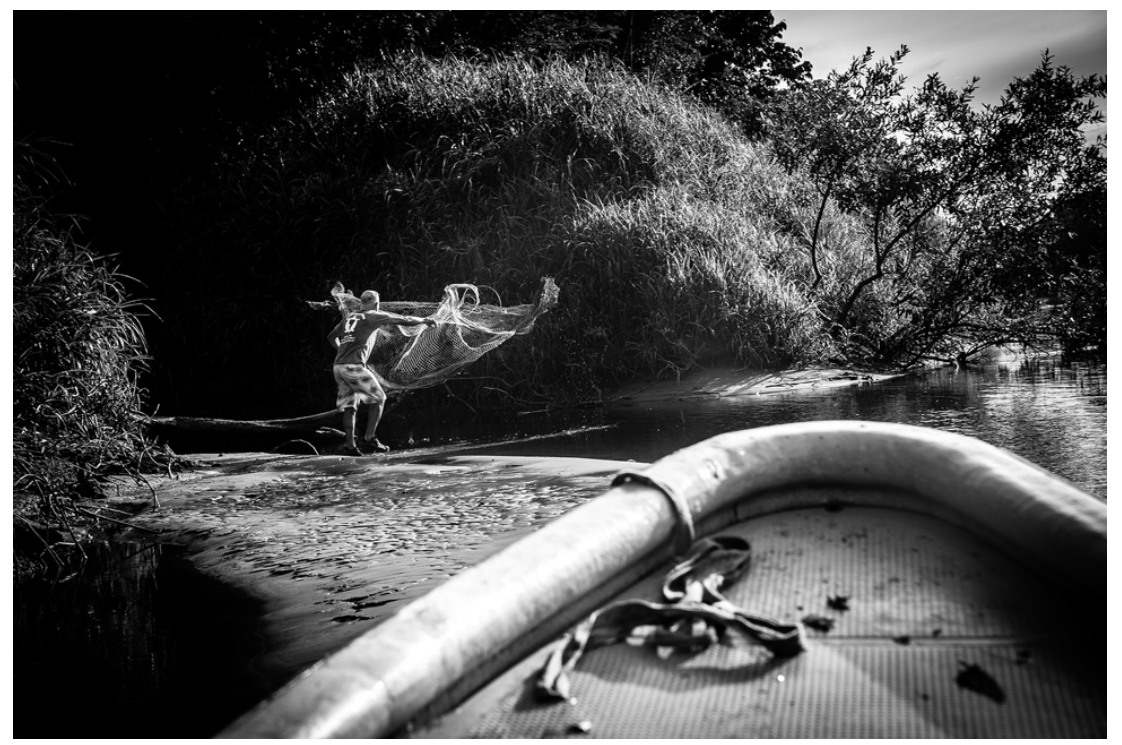

Photo 1: Miguel fishing for dinner (photo by Mark de Rond)

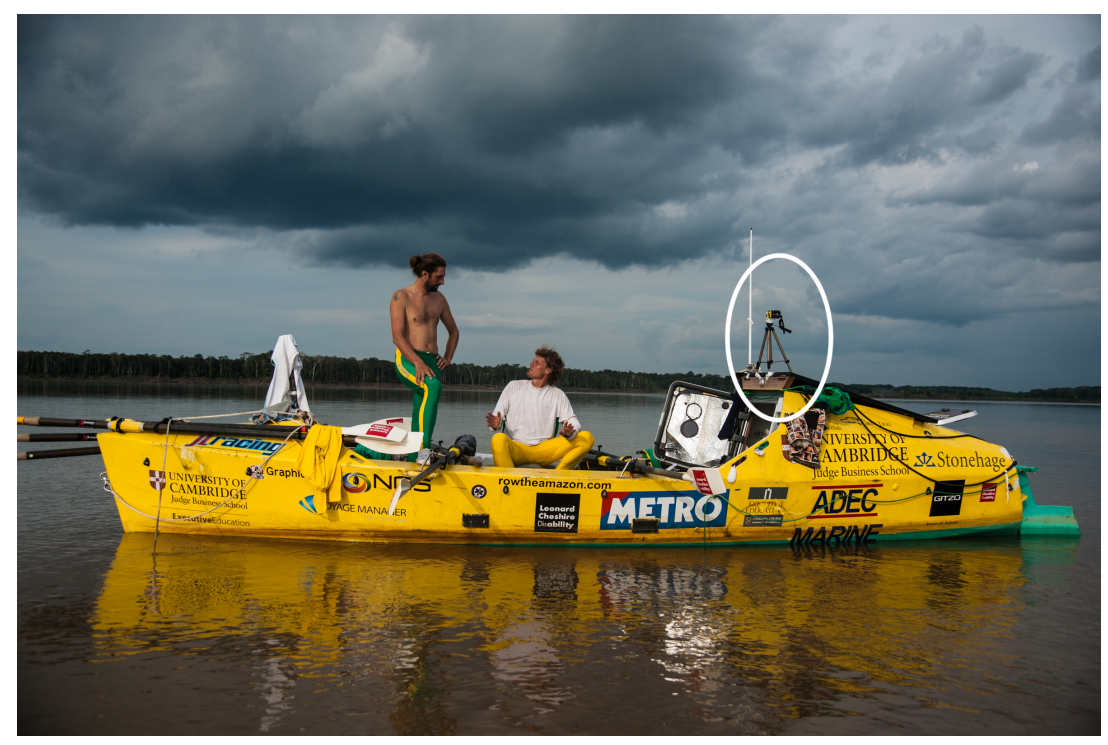

Photo 2: Video camera as mounted on the boat (photo by Miguel) 


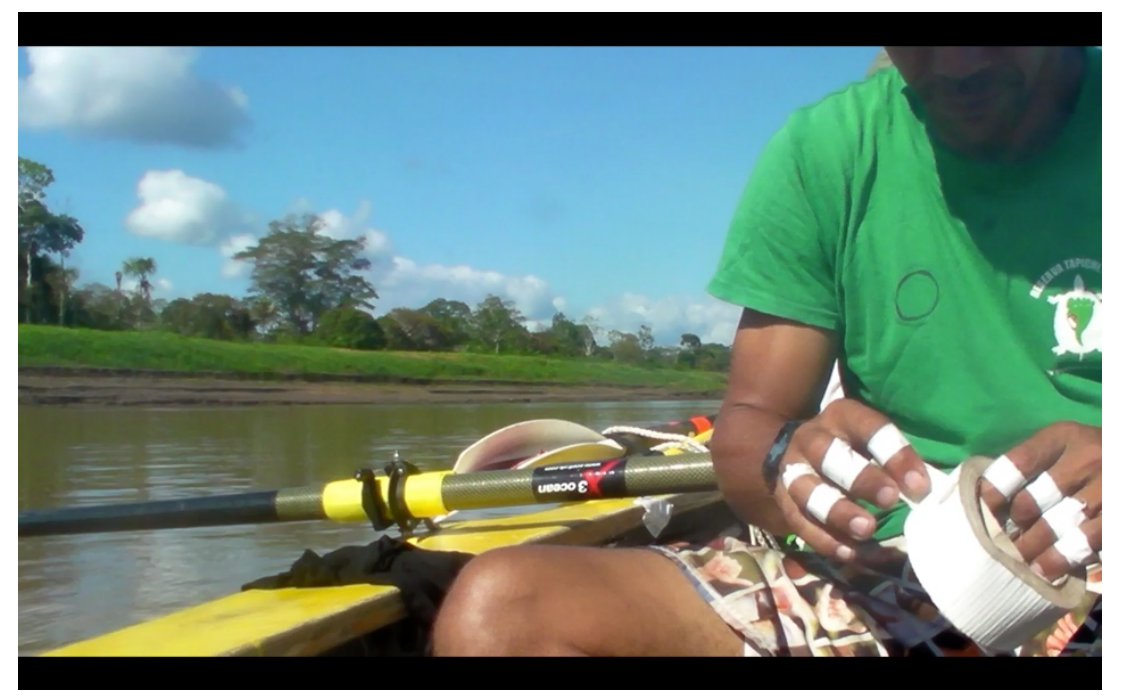

Photo 3: Miguel taping his blistered hands (screenshot from video)

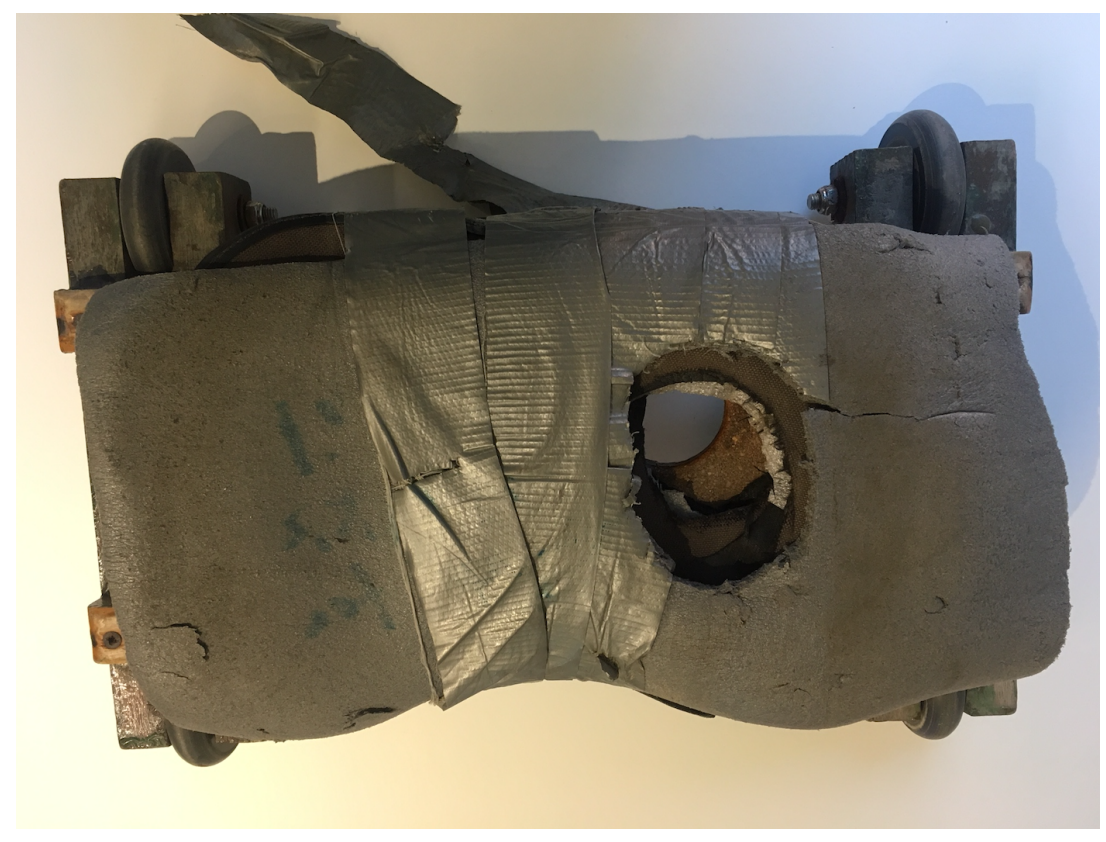

Photo 4: The rowing seat (photo by Mark de Rond) 


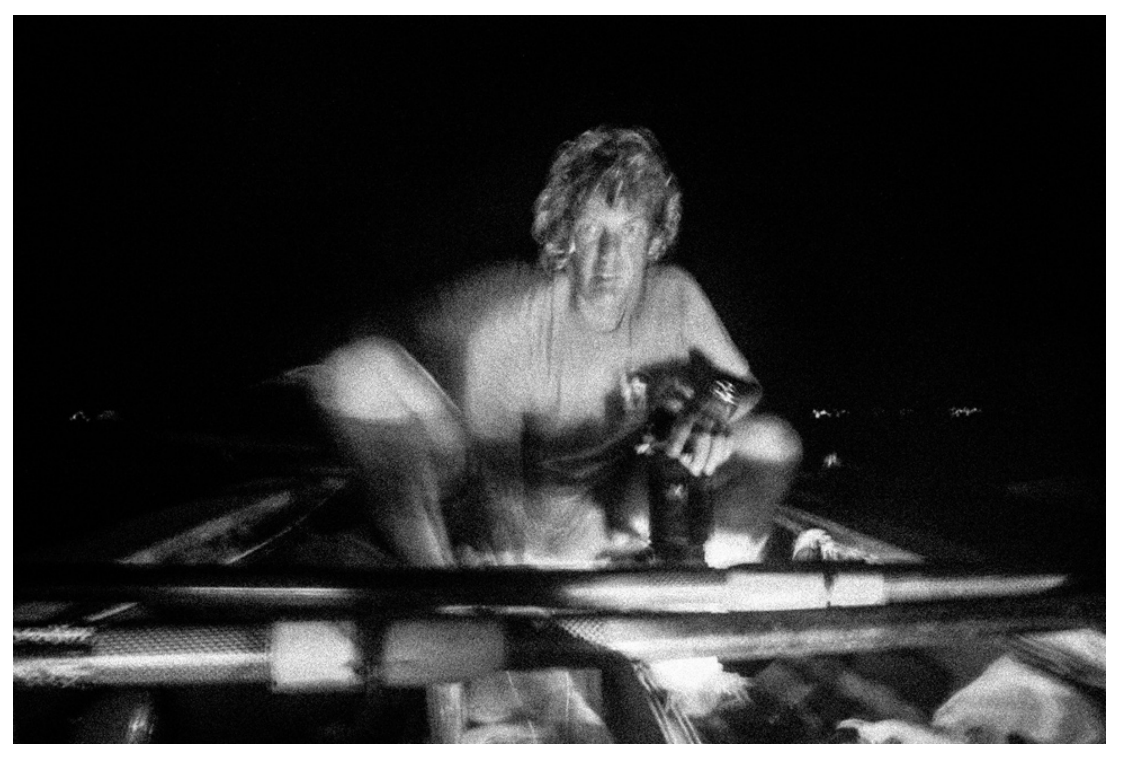

Photo 5: Night-time rowing (photo by Anton Wright)

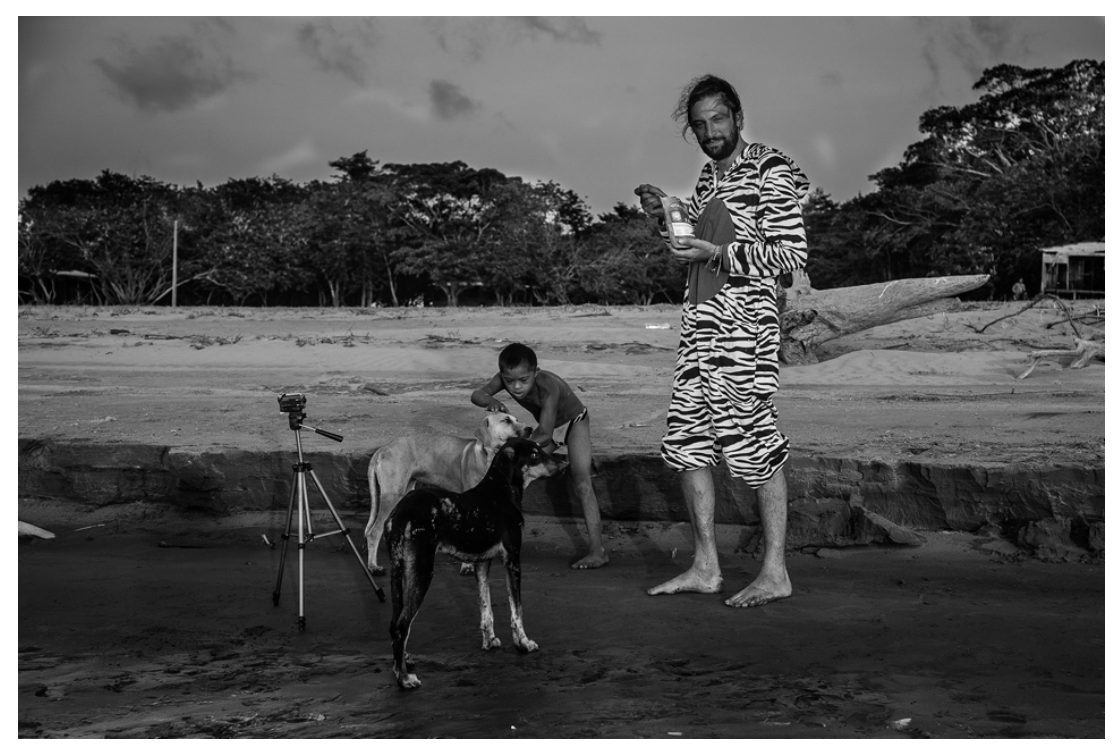

Photo 6: Anton in his zebra-patterned onesie (photo by Mark de Rond) 


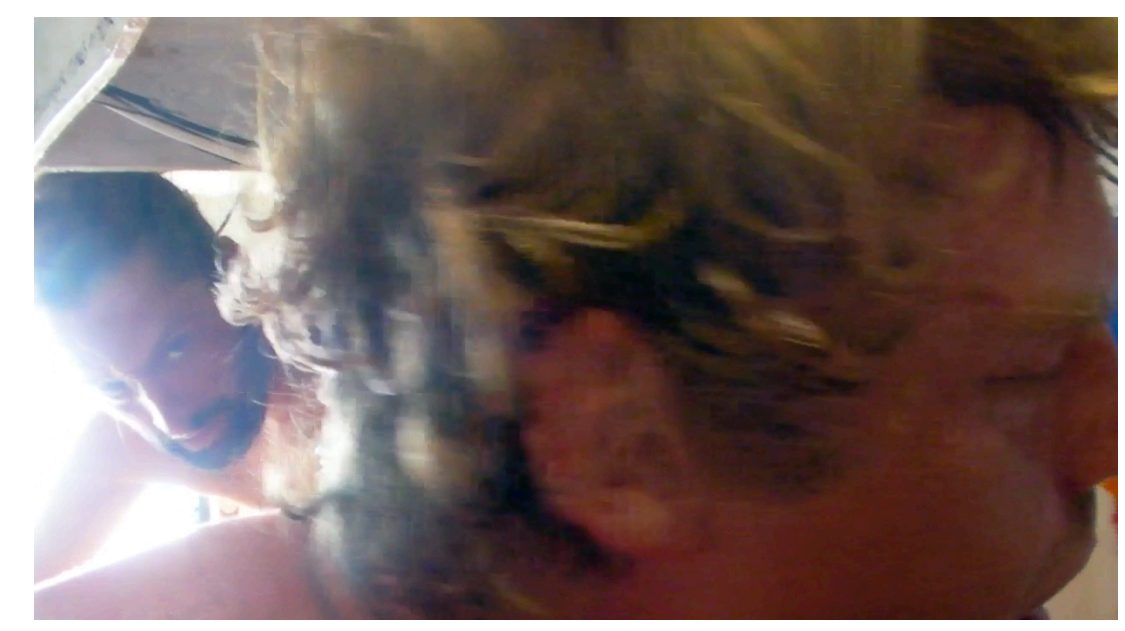

Photo 7: Anton performing minor surgery on Mark (screenshot from video)

Mark de Rond (mejd3@cam.ac.uk) is Professor of Organizational Ethnography at the Cambridge Judge Business School, University of Cambridge. A recurring feature in his work is the experience of being human in (relatively) extreme contexts. His fieldwork has involved extended periods with Boat Race crews, doctors and nurses at war, adventurers, peace activists and, most recently, paedophile hunters.

Isaac Holeman (iholeman@uw.edu) is Clinical Assistant Professor of Global Health at the University of Washington in Seattle, and Chief Research Officer at the non-profit organization Medic Mobile. He recently received his Ph.D. from the University of Cambridge, where he was a Gates Cambridge Scholar at the Cambridge Judge Business School. His research interests include digital health, ethnography, theories of practice, sensemaking, and human-centered design.

Jennifer Howard-Grenville (j.howard-grenville@jbs.cam.ac.uk) is the Diageo Professor of Organization Studies at the Cambridge Judge Business School, University of Cambridge. She contributes to organization theory through in-depth studies of how people work from within to change organizations, communities, and occupations. She is particularly interested in the transformations required to tackle grand challenges, like environmental sustainability. 